\begin{abstract}
UNIVERSIDADE DE BRASÍLIA
Centro de Excelência em Turismo

Curso de Especialização para Professores e Pesquisadores em Turismo

e Hospitalidade
\end{abstract}

\title{
REGGAE: IDENTIDADE CULTURAL E ATRATIVIDADE TURÍSTICA DE SÃO LUÍS DO MARANHÃO
}

Talita Lima Penha

Maria Salete Kern Machado, Doutora em Sociologia Orientadora

Membro da Banca Examinadora

Brasília, DF, 09, dezembro 2003 
Penha, Talita Lima

Reggae, Identidade Cultural e Atratividade Turística de São Luís do

Maranhão / Talita Lima Penha.- Brasília UnB/CET, 2003. Xiii, 77p.:il.

Monografia - (Especialização em Turismo e Hospitalidade) -

Universidade de Brasília, Centro de Excelência em Turismo.

Reggae, Cultural Identity and Turistic Attractive from Sao Luis of the Maranhao.

1. Turismo 2. Maranhão 3. Jamaica 4.Reggae 
TALITA LIMA PENHA

\title{
REGGAE: IDENTIDADE CULTURAL E ATRATIVIDADE TURÍSTICA DE SÃO LUÍS DO MARANHÃO
}

Comissão Avaliadora

\author{
Maria Salete Kern Machado \\ Professora Orientadora
}

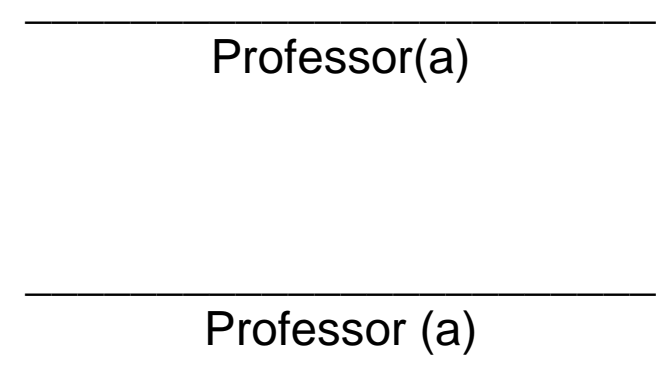

Brasília, DF, 09, dezembro, 2003 
Dedico este trabalho à minha orientadora, professora Maria Salete Kern Machado, pela atenção e apoio a mim dedicados, em especial na escolha do tema; e ao professor Carlos Benedito Rodrigues da Silva, da Universidade Federal do Maranhão, estudioso do reggae e da força negra nas manifestações culturais brasileiras. 
Agradeço, sinceramente,

aos meus familiares;

ao meu namorado;

aos meus alunos da Faculdade Cenecista de Brasília, pela força e paciência nas horas de ausência em que me dedicava ao trabalho;

aos meus primos Jefersson, Ângela e Jackelinne, pela hospitalidade em São Luís, viabilizando a realização da pesquisa;

à professora Nélia, pela ajuda na revisão do trabalho. 
O reggae é uma das formas de resistência cultural do negro contra o etnocentrismo europeu.

Carlos Benedito Rodrigues da Silva 
Conhecida como a cidade de muitas faces, São Luís é atualmente a cidade com a maior diversidade cultural do nordeste, expressando as inúmeras manifestações culturais no calendário anual das festas tradicionais. A cidade dorme ao som dos tambores de minas, tambores de criola, tambores de zabumba, matracas e pandeirões, tocados e dançados pelas mães e pais-de-santo, por crianças, jovens e adultos, que trazem e cultivam as raízes africanas. A juventude negra desperta a negritude ao som e aos embalos do reggae que vem da Jamaica e chega à cidade, como mais uma forma da cultural local, mobilizando as pessoas contra a opressão e o racismo existentes devido à história de escravidão e preconceitos, advindos da colonização européia do Brasil. O reggae é valorizado, principalmente, pelos moradores das periferias, que vêem no ritmo uma alternativa de lazer. Hoje, a classe alta já aceita e busca os salões de reggae. Com o reconhecimento das outras classes sociais, o reggae já pode ser visto como um produto típico local capaz de contribuir para o desenvolvimento tanto socioeconômico quanto turístico de São Luís, contribuindo na valorização das manifestações afro-brasileiras.

Palavras-chave: reggae; cultura negra; desenvolvimento turístico. 


\begin{abstract}
São Luís, is a city also 'knew' as a multiple face city, and is nowadays the one with the biggest cultural diversity in the whole northeast region of the country, expressing the uncountable cultural manifestations in the annual calendar of traditional parties. The city sleeps with the music of tambores de minas, tambores de criola, tambores de zazumba, matracas and panderões, played and danced by the mães and pais-desanto, children, adolescents and adults, which bring and keep their African roots of life. The black youth brings up the black aspects to the music and to the rhythms of the reggae that comes from Jamaica, and arrives at the city as one more local cultural manifestation, gathering the people against the oppression and the racism that exists in the city, due to its slavery and prejudices history brought by the European settling in Brazil. Mainly the people who live in the poor areas and that find in the music an option for leisure value reggae. Today, the higher social and economical classes are already accepting the music and are going to reggae clubs. With this changes, the reggae is considered now a typical local 'product' able to contribute to the social, economical and tourist developments of the city of São Luís, and, consequently, to contribute to the Afro- Brazilian manifestations.
\end{abstract}

Keywords: black culture; reggae; tourist development. 


\section{SUMÁRIO}

LISTA DE FIGURAS

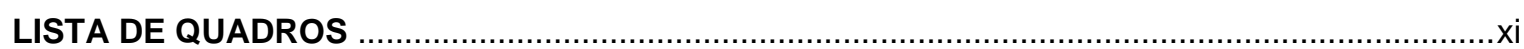

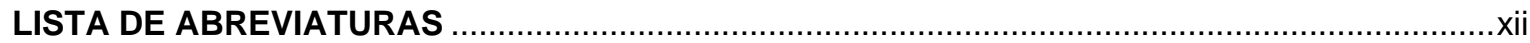

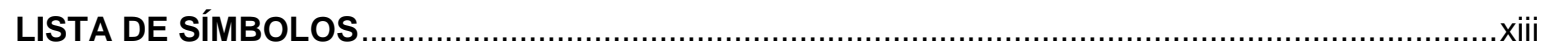

1 INTRODUÇÃO

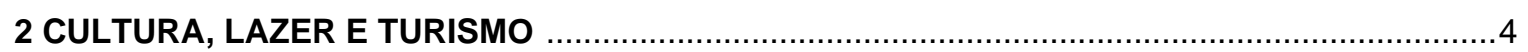

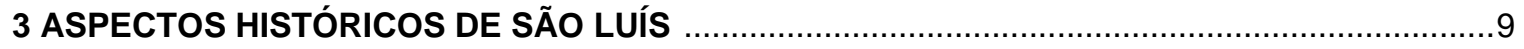

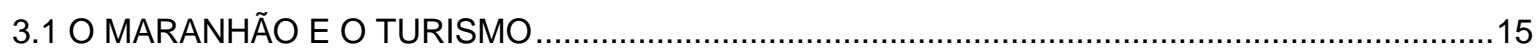

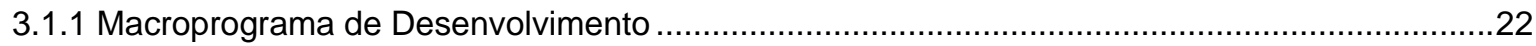

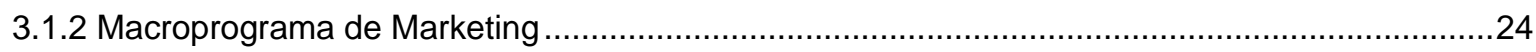

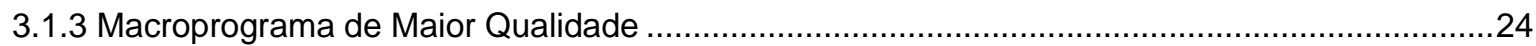

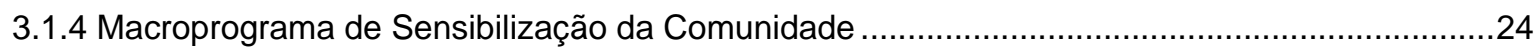

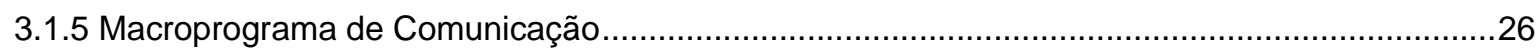

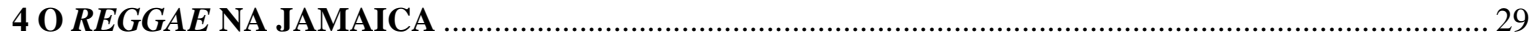

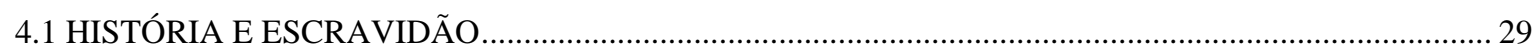

4.2 ABOLIÇÃO DA ESCRAVATURA E CONSEQÜÊNCIAS ………………………………………........ 30

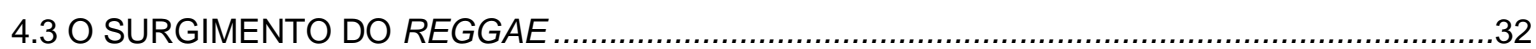

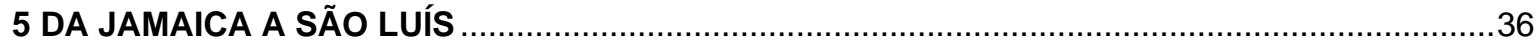

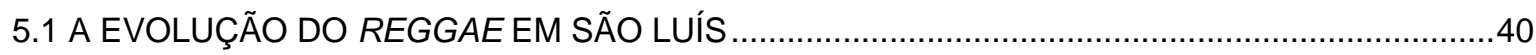

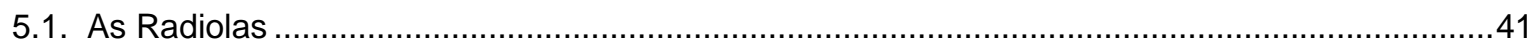

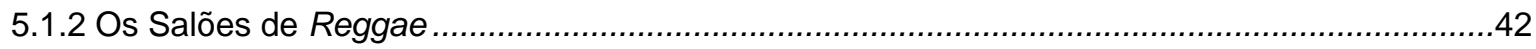

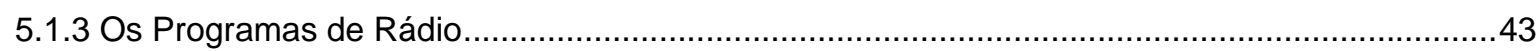

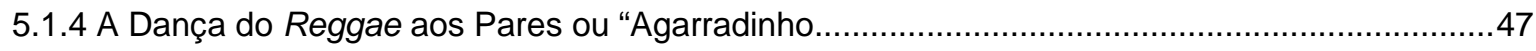

6 O REGGAE COMO ATRATIVO TURÍSTICO DE SÃO LUÍS, MARANHÃO ..................................50

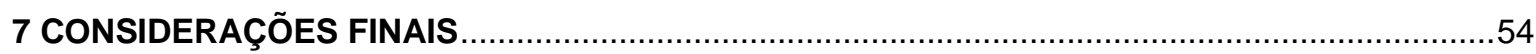

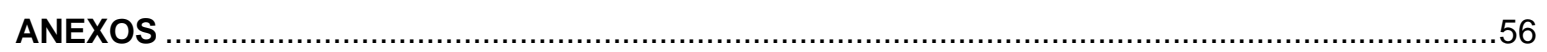

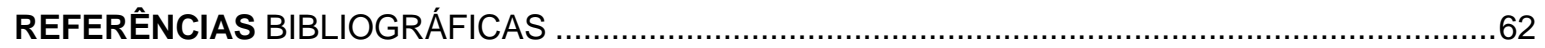




\section{LISTA DE FIGURAS}

FIGURA 1 - GRÁFICO DA EVOLUÇÃO DO MOVIMENTO TURÍSTICO DOMÉSTICO X INTERNACIONAL .....7

FIGURA 2 - GRÁFICO DO PERFIL DO TURISTA QUE VISITA O MARANHÃO............................................ 16 


\section{LISTA DE QUADROS}

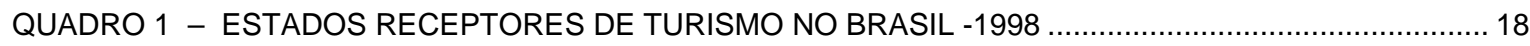

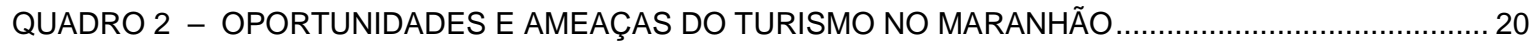

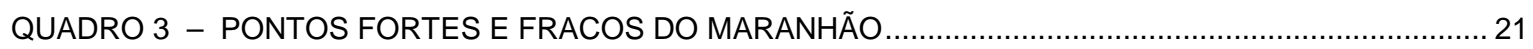

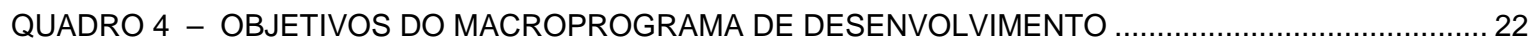

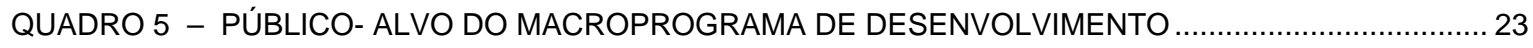

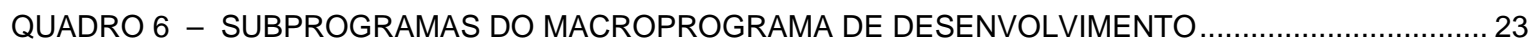

QUADRO 7 - OBJETIVOS DO MACROPROGRAMA DE SENSIBILIZAÇÃO DA COMUNIDADE ....................2 25

QUADRO 8 - PÚBLICO-ALVO DO MACROPROGRAMA DE SENSIBILIZAÇÃO DA COMUNIDADE …........... 25

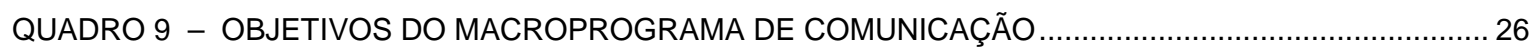

QUADRO 10 - PÚBLICO-ALVO DO MACROPROGRAMA DE COMUNICAÇÃO............................................... 27 


\section{LISTA DE ABREVIATURAS}

DEPEM .................EEPARTAMENTO DE PROJETOS ESPECIAIS DE MODERNIZAÇÃO E QUALIFICAÇÃO DO
ENSINO SUPERIOR
EMBRATUR............INSTITUTO BRASILEIRO DE TURISMO
FIPE ..................FUNDAÇÃO INSTITUTO DE PESQUISAS ECONÔMICAS
FOFA................ FORTES OPORTUNIDADES E FRACAS AMEAÇAS
IPES ................... INSTITUTO DE PESQUISA E ESTUDOS SOCIAIS
UNESCO …......... ORGANIZAÇÃO DAS NAÇÕES UNIDAS PARA A EDUCAÇÃO, A CIÊNCIA E A CULTURA


LISTA DE SÍMBOLOS

\% …….................. PORCENTAGEM

KM ............................QUILÔMETRO 


\section{INTRODUÇÃO}

A sociedade ludovicense ${ }^{1}$ vive um momento marcante em sua trajetória. São Luís do Maranhão é reconhecida atualmente como Patrimônio Histórico da Humanidade, o que a transporta para maior nível em atratividade turística.

O presente estudo enfoca a temática do reggae como aspecto da identidade local e como manifestação cultural capaz de atrair turistas, contribuindo para o desenvolvimento turístico de São Luís.

Rememorando-se a surpreendente história local, descobre-se que a colonização européia, representada pelas civilizações francesa, portuguesa e holandesa, influenciou na construção da identidade maranhense. A influência é visível em artesanatos e em edificações decoradas com azulejos. Na música, São Luís teve influência forte do ritmo afro-caribenho com aceitação nos vários segmentos da sociedade. O poder de sedução, que o ritmo exerce sobre os turistas, tornou imprescindível sua valorização, contribuindo imensamente para que o interesse pessoal fosse elevado à categoria de Pesquisa Monográfica.

Presente na maioria das programações de rádio, o reggae leva o mais novo membro do Patrimônio Histórico da Humanidade a ser conhecido como "Capital Brasileira do reggae", ou "Jamaica Brasileira", oferecendo à cidade de São Luís do Maranhão mais uma referência turística: mais opções de lazer e cultura.

Dessa forma, avaliou-se a aceitação do reggae pelos turistas e pela comunidade local, como também sua venda como produto turístico, estabelecendo-se parâmetros entre a cultura e o turismo como forma de desenvolvimento; investigando como tal manifestação cultural acontece e como é divulgada; verificou-se junto às agências e à Secretaria de Turismo como se dá o apoio, principalmente na área promocional e de venda do reggae

\footnotetext{
${ }^{1}$ Ludovicense refere-se à pessoa que nasce em São Luís, no Maranhão.
} 
Para melhor desenvolvimento desta pesquisa, revisaram-se a história e a literatura, utilizando-se jornais de circulação local, revistas nacionais, livros, além de visitas aos locais onde acontecem eventos relacionados à expressão do reggae, tendo em vista a descrição de espaços físicos. Efetuaram-se contatos com proprietários de estabelecimentos, especulando-Ihes as opiniões em relação ao movimento reggae e buscando entendimento de como se deu o desenvolvimento do ritmo na Jamaica e sua aceitação no Maranhão.

Realizaram-se também, entrevistas com freqüentadores das festas de reggae, objetivando-se a coleta de opiniões e de sugestões, para explicitação do nível de veracidade, autenticidade e aproveitamento deste estudo no âmbito do turismo, concebendo-se a idéia de que, por meio dos dados, futuros pesquisadores passem a ter uma visão geral do movimento reggae e da sua potencialidade como atrativo turístico.

É importante salientar que os freqüentadores dos salões de reggae, tanto nativos quanto turistas, admiram e respeitam aqueles que buscam conhecer a "essência" do reggae, contribuindo valiosamente para a pesquisa. Por outro lado, os tradicionalistas preferem não falar sobre o ritmo e se recusam, muitas vezes, em aceitá-lo como parte da história local, mesmo convivendo há mais de trinta anos com ele na ilha.

Para que o desenvolvimento do tema proposto possa ser entendido de maneira prática, serão relacionados, a seguir, alguns aspectos dos capítulos tratados no transcorrer da pesquisa:

a) relação entre cultura, lazer, turismo, e como o reggae comprovaria a importância do ritmo dentro do contexto social local;

b) exposição de aspectos históricos de São Luís com comentários sobre a grande variedade cultural advinda da facilidade com que absorveu o ritmo reggae em sua cultura local, evidenciando-se posteriormente, como elemento importante para atrair turistas; 
c) relato de como se deu a história do reggae na Jamaica, descrevendo-se questões socioeconômicas, políticas e culturais, desde os primórdios da escravidão até a época da abolição, tratando da sua expansão pelo mundo;

d) descrição de aspectos do reggae no Maranhão, sua origem e evolução em salões de festas, radiolas e programas de rádio, e de como ele se constitui atrativo, sugerindo-se uma proposta de circuito opcional de lazer direcionado ao reggae. 


\section{CULTURA, LAZER E TURISMO}

O homem, em toda sua existência, tem sido capaz de acumular experiências, e testá-las no cotidiano. Ao serem absorvidas através dos tempos, transformaram-se em atos e costumes de viver.

Passados de geração a geração, tais costumes foram ajustando-se ao desenvolvimento e à modernização dos tempos. São as manifestações, como as expressões dos desejos, as ideologias e a filosofia peculiares do indivíduo e de seu cotidiano, que formatarão a cultura local. Segundo Meneses (2002, pág.92)

A cultura é um universo historicamente criado, os sentidos e valores que o sustentam precisam ser explicitados, declarados, propostos. Em outras palavras, os valores culturais não são espontâneos, não se impõem por si próprios, não nascem com o indivíduo, não são produto da natureza. Decorrem da ação social. As relações e opções feitas pelos indivíduos e grupos, para serem socializados e se transformarem em padrões, necessitam de mecanismos de identificação, enculturação, aceitação.

A cultura diz respeito à forma de vida de uma sociedade e à expressão de costumes, hábitos, tradições e formas de organização, dentre as quais encontra-se o trabalho, como uma atividade inerentemente ligada ao homem e ao seu desenvolvimento, permeado de satisfação e liberdade.

O trabalho é visto como "atividade humana por excelência, em que o homem transforma a si mesmo e à natureza. Mas, nos sistemas onde persiste a exploração, ao invés de contribuir para seu desenvolvimento, torna-se condição de sua alienação" (ARRUDA; MARTINS, 1986, pág.1).

Os trabalhos realizados por artesãos, operários e camponeses, antes da Revolução Industrial, seguiam o ritmo da natureza. Começava-se a trabalhar ao clarear do dia, às $3 \mathrm{~h}$ da manhã, parando ao cair da noite, entre 22h e 22h30, com média diária de 19 horas de trabalho - isso devido à precária iluminação, que não permitia a continuidade do trabalho. Seguia-se o ritmo das estações, pois o plantio da semente requeria muito tempo, assim como a colheita. 
As jornadas de trabalho, com o tempo foram diminuindo. Com a Revolução Industrial houve o crescimento das cidades e o desenvolvimento tecnológico e cultural do homem. A melhor divisão técnica do trabalho e a melhor organização das tarefas, mediante tempo cronometrado, permitiu o aumento da produção e da produtividade.

Entretanto, as condições do proletariado eram precárias e, devido às insatisfações, cria-se o movimento contra a exploração e a falta de descanso.

Com a movimentação, algumas fábricas, em 1802, reduziram o horário de trabalho para 12 horas diárias, e lentamente os operários conquistaram o descanso semanal em 1850. Já em 1919, foi votada a lei das oito horas de carga horária trabalhista. Logo, dá-se a redução progressiva da semana de trabalho para cinco dias. Posteriormente, em 1930, o descanso passou a ser remunerado (BARRETO, 2002, pág.60-61).

No início do século XXI, países como Japão adotaram 35 horas semanais de trabalho, o que aumenta consideravelmente 0 tempo livre, favorecendo 0 desenvolvimento do turismo, buscando-se viagens e lazer para preencher o tempo de descanso. O lazer, portanto:

É um conjunto de ocupações às quais os indivíduos podem entregar-se de livre e espontânea vontade, seja para repousar, seja para divertir-se, recrear-se e entreterse, ou ainda para desenvolver a sua informação ou formação desinteressada, sua participação social ou sua livre capacidade criadora, após liberar-se das obrigações familiares ou sociais (DUMAZEDEIER 1973, pág. 34).

$\mathrm{Na}$ relação homem e trabalho há necessidade premente do tempo livre, fundamental para reposição de energias, eliminação da fadiga, possibilitando a que o homem almeje o divertimento, a recreação e o entretenimento que proporciona equilíbrio psicológico, além de possibilitar uma participação social mais livre, com alternativas de viagens para sair em busca de conhecimentos culturais diferentes e prazerosos. 
Verifica-se que parte do lazer desenvolve-se no âmbito das viagens, sendo o turismo a maneira mais atraente de tal realização já que oferece, além de descanso e distração, também intercâmbio cultural.

O turismo tornou-se o primeiro instrumento de compreensão entre os povos; ele permite o encontro dos seres humanos que habitam regiões mais afastadas e são de língua, raça, religião e orientação política e econômica diferentes. Ele os reúne e é graças a ele, em grande parte, que estes seres humanos conseguem estabelecer um diálogo entre si, compreender a mentalidade do outro que de longe the parece tão estranho, preenchendo desta forma o fosso que os separa. (KRIPPENDORF, 1998, pág.105).

A separação existe pelo fato de cada ser participar e advir de uma cultura própria, capaz de atrair turistas em busca do diferente e, muitas vezes, do desconhecido.

Dentre os vários tipos de turismo, há o turismo cultural que se resume na busca do turista em conhecer culturas que diferem da sua, ou seja,

O turismo cultural no sentido mais amplo seria aquele que não tem como atrativo principal um recurso natural. As coisas feitas pelo homem constituem a oferta cultural, portanto turismo cultural seria aquele cujo objetivo é conhecer os bens materiais e imateriais produzidos pelo homem, como artesanato, música, dança (BARRETO, 1995, pág. 21).

A estreita relação entre o turismo e a cultura constitui um corpo único, que contribui com efeito favorável para o desenvolvimento do homem e a promoção cultural da sociedade de um modo geral. Além da projeção cultural, o turismo proporciona para muitos países, um incremento na economia, inserindo-se como um dos setores fortes no âmbito econômico mundial, possibilitando a geração de empregos diretos e indiretos, investimentos locais, redistribuição de renda, além da injeção de divisas oriundas de outros países.

O Brasil, tendo dimensões continentais, possui grandes possibilidades de se desenvolver com o turismo, seja explorando os aspectos naturais riquíssimos, seja mostrando os aspectos culturais, bem diversificados. Isso se deve, principalmente, à formação étnica do povo brasileiro, que possui características do branco, do negro e do índio. Os estrangeiros que aqui chegaram, trouxeram consigo uma diversidade cultural muito forte, verificada em hábitos, valores, usos e costumes, desde o período colonial. 
Dentre os estrangeiros que colonizaram o Brasil, havia os negros, povo proveniente da África, que vieram para trabalhar sob regime de escravidão nas lavouras. Deram grande contribuição para a formação cultural brasileira com danças, culinária, vestimentas, tudo favorável ao clima tropical.

No início do século XX, o turismo tornou-se, em todo o mundo, uma atividade marcante, tanto no âmbito econômico, quanto no sociocultural, ocupando local de destaque no bom relacionamento entre as nações e promovendo o enriquecimento econômico e cultural entre elas.

No Brasil, a evolução começou a partir de 1995, com o aumento considerável de turistas viajando e visitando as regiões do país, desenvolvendo, assim o turismo interno e valorizando atrativos locais.

GRÁFICO 1- EVOLUÇÃO DO MOVIMENTO TURÍSTICO DOMÉSTICO X INTERNACIONAL

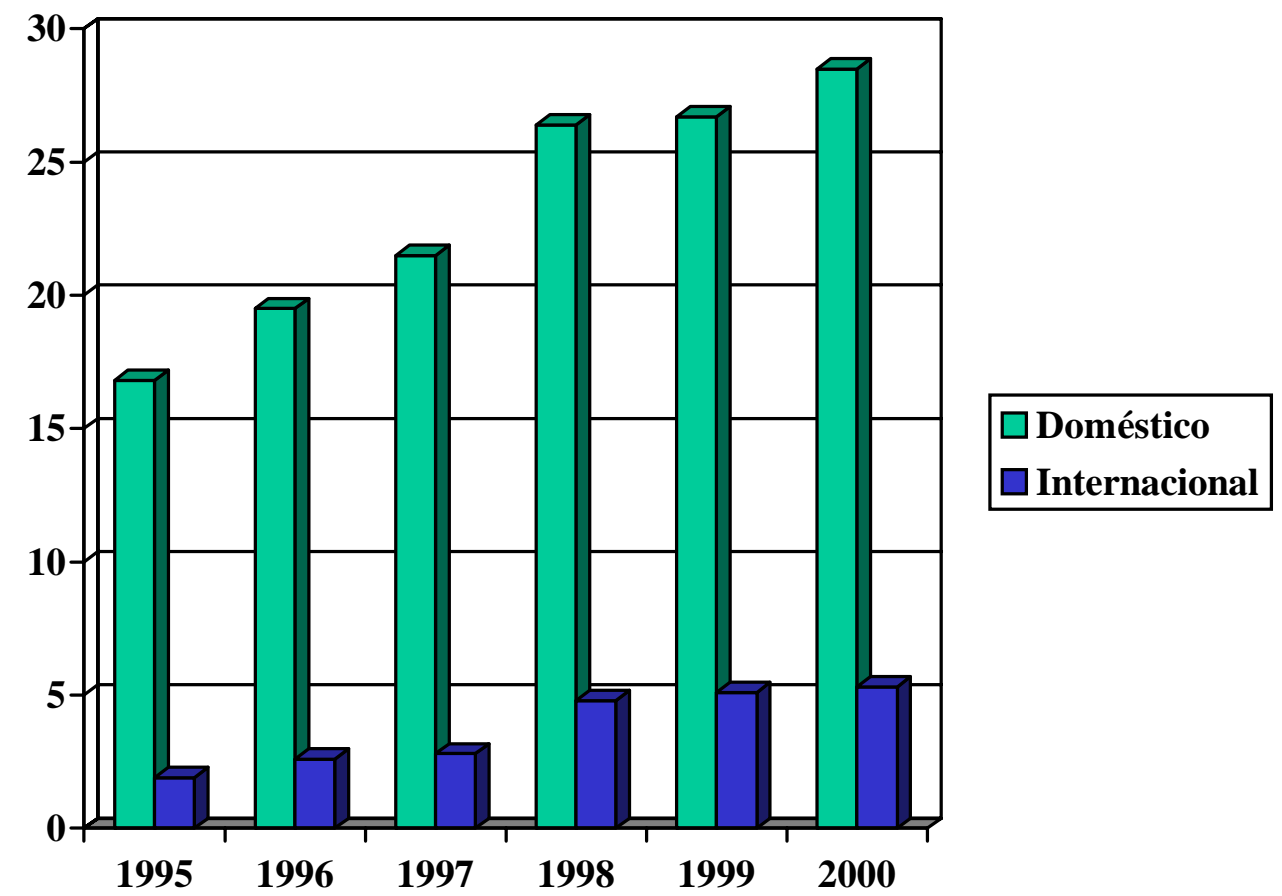

Fonte: FIPE - Estudo de Mercado Doméstico

O Maranhão é exemplo de grande centro cultural brasileiro por possuir atrativos folclóricos como o bumba-meu-boi, o tambor de criola, o cacuriá, a dança do lelê e, mais recentemente, o reggae. 
O reggae nasceu na África, advindo de mensagens sociais contra a opressão, em forma de protesto contra a discriminação racial. O ritmo tem uma forma de identificação cultural sem limites com relações muito próximas das estabelecidas pela população negra do Maranhão que o procura como maneira de romper as angústias do cotidiano, tentando assim, transpor barreiras de desigualdade social. 


\section{ASPECTOS HISTÓRICOS DE SÃO LUÍS}

Conforme literatura a respeito da história de São Luís, Mesquita ${ }^{2}$ (1995, pág.4) informa que a ilha de São Luís era habitada no século que antecedeu ao seu descobrimento pelos franceses, por índios tupinambás. "Por acaso", alguns piratas franceses, como Charles De Vaux, perderam-se na costa brasileira e lá ancoraram seus barcos. Com o passar dos dias, Charles De Vaux conseguiu voltar à França. Tendo descoberto riquezas como pau-brasil, algodão, fumo e minas de ouro, prata e enxofre, Charles De Vaux convenceu o rei Henrique IV a conquistar as terras desprezadas. O rei decide, então, confiar tal tarefa ao nobre Daniel de La Touche, conhecido como Senhor de La Ravardière, dando início ao sonho dos franceses de implantar em terras maranhenses uma França Equinocial.

Essa história aconteceu há quase quatro séculos, no ano de 1612. Era mês de agosto, quando La Ravardière chegou com o reforço de uma esquadra de 500 homens, sendo recebido com festas pelos índios. No dia 12 de mesmo mês, a primeira missa foi celebrada e teve início a construção do Forte de Saint Louis, ao pé de uma nascente. Começava uma convivência amigável entre os franceses e os índios, que colaboraram prazerosamente em todo o trabalho de instalação da colônia. O respeito era tão mútuo que os colonizadores chegavam a punir com a pena de morte, 'sem esperança de remissão', autores de discursos feitos com o intento de desgostar os habitantes. As alianças se estendiam ao interior e, aos poucos, os franceses ampliaram o seu domínio na região".

A terra, porém, já era dos portugueses, que logo despertaram para a grande conquista do norte, porta aberta para os lendários tesouros do Amazonas e Peru. Eles expulsaram os franceses três anos mais tarde, na famosa Batalha de Gaxenduba, em que até um milagre é atribuído à vitória lusitana. Conta-se que a própria Virgem Maria teria transformado areia em pólvora, revigorando os atacantes com a santa presença. Os portugueses rebatizaram o Forte com o nome de São Felipe e fundaram, em 1621, o Estado do Maranhão e Grão Pará, separado do resto do Brasil. Houve ainda, novos inimigos. Os holandeses, que chegaram em 1641 e dominaram o território durante três anos. Apenas em 1644, Portugal conseguiu retomar o domínio definitivo da ilha, onde seria construída a capital mais lusitana do país, sendo que o nome francês permaneceu como São Luís.

\footnotetext{
${ }^{2}$ Fernando César Mesquita - Secretário do Meio Ambiente e Turismo do Maranhão no ano de 1995.
} 
Os portugueses trataram de expandir seus negócios e, no final do século XVIII, o Maranhão atingia o apogeu econômico com os ciclos do algodão e do açúcar, que contribuíram para o aumento da ocupação do território da ilha e áreas mais próximas, evidenciando a região como fabricante de tecidos de alta qualidade. Foi nesta época que as famílias abastadas mandavam os filhos estudarem na Europa, andavam de bondes e carruagens e traziam de Lisboa os azulejos e móveis para decorar suas residências. Já no século XIX, o Maranhão chegou a ser a quarta cidade brasileira em população, consolidando-se economicamente, com a abertura de fábricas têxteis, sendo seis somente na capital.

Com tal ampliação de mercado, o enorme contigente exigia mais mão - de obra escrava, antes formada por índios. Não se deu de forma passiva, mas com protestos violentos, mas, a verdade é que a mão-de-obra escrava índia foi perdendo o valor, devendo-se este fato ao temperamento e aos costumes, pois os índios estavam habituados à liberdade da vida nômade das florestas, dos descampados e das praias. Os portugueses reconheceram que o índio não se constituía no ideal de trabalhador que a colônia portuguesa precisava.

Quando os índios não fugiam à sujeição, embrenhavam-se novamente nas matas ou se deixavam facilmente morrer de tédio. Fracassada a escravidão do gentio, começou a substituição da mão - de - obra escrava indígena pela mão africana.

Entre 1757 e 1777, entraram no porto de São Luís 12.567 escravos, sendo constante o movimento de navios negreiros no Golfo do Maranhão. Os negros eram conduzidos a trabalhos forçados com condições subumanas, duramente castigados em caso de resistência.

Luna afirma que

A maioria dos senhores de escravos tratava o cativo como animal de serviço, abaixo do cavalo de sela e no mesmo plano de boi de carro e do burro de carga, embora estes fossem menos infelizes, por falta de consciência para alcançar o horror da humilhação. Cavalos, burros e bois estavam livres da tirania do tronco, 
dos bolos de palmatória, do suplício das máscaras de flandres, das torturas das prisões em solitárias soturnas, da agonia de longos jejuns, da ignorância dos grilhões e de todas as formas de desumanos e humilhantes castigos físicos e morais". (LUNA 1976, pág. 24)

A Revista Maranhense de Cultura (1974, pág. 30) informa que no século XIX ocorreram fatos históricos em nível nacional que, por conseqüência, abalaram intensamente a economia ludovicense: a Independência do Brasil em 1822 e a Abolição da Escravatura em 1889. São Luís do Maranhão, nessa época, continha um grande número de casarões, praças, igrejas, etc., de imensa valia patrimonial. Fora agraciada pelas culturas portuguesa e francesa com seus fabulosos conhecimentos arquitetônicos e artísticos e, como presente da modernidade, passou a denominar-se Patrimônio Histórico da Humanidade, título concedido pela Organização das Nações Unidas para a Educação, a Ciência e a Cultura - UNESCO, por ostentar o mais harmonioso conjunto colonial português na América Latina. Reúne mais de 3500 edificações dos séculos XVIII e XIX, possibilitando ao turista a vertiginosa sensação de uma viagem através do tempo. Portanto, o patrimônio Histórico e Artístico é tudo aquilo que

Abrange os bens imóveis, existentes em determinada localidade, cuja conservação seja de interesse público, por sua vinculação a fatos memoráveis da história pátria ou por seu valor artístico, arqueológico, etnográfico, bibliográfico ou ambiental (MEIRELES, 1990, pág. 22).

Notam-se a riqueza e a importância do patrimônio local por meio:

a) das características detalhadas dos enormes casarões, cujas fachadas são embelezadas por azulejos vindos de Portugal ou da França;

b) das ruas estreitas, cortadas por becos de nomes capazes de "causar espanto" a qualquer visitante inusitado;

c) das antigas igrejas, ricamente adornadas, freqüentadas no passado por pessoas, não menos belas e suntuosas; 
d) de seus mercados seculares, onde se pode encontrar todo tipo de fruta tropical, espécies variadas de alimentos vegetais e animais, além de bugigangas de esmalte, barro, palha, etc.

e) de praias generosas pela sua beleza natural.

Em nenhuma cidade brasileira, os portugueses usaram tanto os azulejos. Conta-se que o clima quente e úmido e os constantes ventos marinhos, carregados de salinidade estragavam tanto o reboco e a caiação das casas, que o jeito foi protegêlos com azulejos. Isto, é claro, sem considerar que o azulejo aparece como elemento característico da arquitetura portuguesa dos séculos XVIII e XIX. Em São Luís, eles estão em toda parte - fachadas, pátio, salas, corredores, escadarias, fontes com padronagens variadas com flores, bichos, motivos geométricos. Foram trazidos principalmente de Portugal, mas também da França, Bélgica e Alemanha. (Fonte: São Luís no bolso - Governo do Estado do Maranhão, 1995).

Os azulejos são apenas um dos aspectos interessantes do rico acervo arquitetônico de São Luís, considerado o maior e mais homogêneo de toda a América Latina. Outro detalhe curioso é que, ao contrário de outras cidades históricas do país, que se destacam pela suntuosidade de sua arquitetura religiosa, em São Luís sobressai a beleza das linhas arquitetônicas de seu casario colonial, mirantes, escadarias, fontes, beirais. As ruas recobertas com pedras de cantaria, becos, travessas e largos tornam o conjunto ainda mais fascinante, principalmente depois que o centro histórico começou a ser recuperado e revitalizado pelo Projeto Reviver ${ }^{3}$.

Em visita à cidade no mês de junho de 2003, percebeu-se que São Luís chega aos 391 anos, conservando seu patrimônio arquitetônico, porém, encontra-se em pleno século XXI, possuindo um Porto Modelo (Porto do Itaqui), um aeroporto moderno com infra-estrutura para receber vôos internacionais, uma bela via litorânea, que circunda a

\footnotetext{
${ }^{3}$ Projeto inaugurado na década de 80 , pelo qual o Governo maranhense restaurou cerca de 200 casarões no bairro da Praia Grande, no centro histórico de São Luís, investindo na conservação. Hoje é proibido o tráfico de veículos; o calçamento é igual ao tempo do Império; os postes de iluminação foram substituídos por lampiões.
} 
orla marítima, em fase de expansão e um projeto de urbanização da Lagoa da Jansen ${ }^{4}$ que prevê a construção de praças, ciclovia, concha acústica, espaço coberto para eventos, bares e pier para esportes náuticos.

Além de todo o patrimônio arquitetônico e natural, tem-se um rico patrimônio cultural: lendas, histórias, danças folclóricas, literatura, não se esquecendo de que São Luís foi conhecida como "Atenas Brasileira" ou "Terra dos Poetas", devido aos grandes nomes da literatura brasileira que lá nasceram. É a musa eterna de poetas e escritores como Gonçalves Dias e Aluízio de Azevedo. Tem hoje, como maior atração cultural, o patrimônio folclórico riquíssimo. Bandeira Tribuzi, poeta da cidade, descreve sua paixão pela cidade:

Ó minha cidade, deixa-me viver que eu quero aprender tua poesia, quero ler nas ruas, fontes contarias, torres e mirantes, igrejas e sobrados, nas lendas ladeiras que cobrem angústias, sonhos do futuro, glórias do passado ( apud Revista Viagem e Turismo, 2001, pág. 23).

São Luís também é conhecida pelos apelidos: "A Ilha Rebelde" - por causa dos movimentos históricos, tanto políticos quanto estudantis; "A Ilha do Amor"; "Ilha dos Mil Odores"; "Capital Mundial dos Azulejos" - devido ao grande número de sobradões coloniais portugueses revestidos de azulejos; "A Ilha Maravilhosa" - devido à sua riqueza folclórica, cultural e artística; "A Jamaica Brasileira" - por ter a maioria da população adotado o reggae como ritmo da ilha, com destaque para os bailes de Radiola; "A Ilha Encantada" - por suas lendas e crendices, como a da carruagem de Ana Jansen na Rua de São Pantaleão; a serpente encantada que dorme nos subterrâneos da cidade, e Nossa Senhora da Vitória que transformou areia em pólvora.

São dezenas as manifestações típicas, mistura de costumes e tradições dos negros, índios e brancos, que resultaram no artesanato criativo, na culinária farta e saborosa.

\footnotetext{
${ }^{4}$ Lagoa da Jansen: encontra-se localizada na parte nobre da cidade, considerada um dos pontos turísticos mais visitados de São Luís, por sua beleza e pelo lazer que proporciona aos turistas.
} 
A mistura se deu quando os franceses introduziram os nativos tupinambás nas danças da Corte, os portugueses trouxeram o gosto pela boa comida e as festas dos dias de santo. Os negros das quarenta tribos Gege-Nagô, desembarcados como escravos, acrescentaram os tambores de mina e de criola e o culto aos orixás; os nordestinos, durante o ciclo do gado, introduziram as toadas de boi.

Não é à toa que o povo maranhense tem um espírito festivo. O calendário de eventos da cidade oferece festas o ano todo, mas é com o ato popular do Bumba-meuboi, realizado no mês de junho, que a cidade se envolve inteiramente ao som das matracas, orquestras e pandeirões.

O auto é uma sátira à opulência dos senhores de engenho, baseada nas histórias de Pai Francisco e Catirina, um casal de escravos negros. Pai Francisco rouba e mata um boi da fazenda de seu amo para satisfazer o desejo da esposa de comer a língua do animal, mas é descoberto. Mas o boi ressuscita de modo fantástico, geralmente após várias rezas e toadas. Pai Francisco é perdoado e tudo vira festa (Fonte: São Luís no bolso - Governo do Estado do Maranhão, 1995).

Além do Bumba-meu-boi, que impressiona pela beleza cênica e a empolgação dos brincantes, existem dezenas de outras manifestações folclóricas bastante populares, como o Tambor de Criola (espécie de samba de roda, com variadas coreografias ao som de atabaques); Tambor de Mina (denominação maranhense para o candomblé); Dança do Coco, Dança do Cacuriá (dança sensual que retrata as posições do ato sexual entre casais); Dança de São Gonçalo, Festa do Divino (em homenagem à descida do Espírito Santo sobre os apóstolos, a um imperador e a uma imperatriz fictícios).

Na última década, São Luís ganhou mais uma tradição: o reggae, ritmo jamaicano que se transformou em um verdadeiro fenômeno, principalmente entre a população negra. Por isso, a cidade ganhou mais um título: a de "Capital Brasileira do Reggae". O ritmo, dançado agarradinho em amplos salões nas praias, na periferia e até nos clubes chiques, sai de potentes radiolas que mais parecem edifícios fonográficos. 


\subsection{O MARANHÃO E O TURISMO}

O turismo é uma vocação natural do Maranhão. A diversidade natural, o passado histórico, a culinária exótica e saborosa e a cultura original e viva tornam o produto turístico Maranhão uma mercadoria cobiçada no emergente mercado do turismo ecológico e cultural.

O imenso potencial turístico do Maranhão sempre foi reconhecido como um dos mais importantes recursos estratégicos para a promoção de seu desenvolvimento econômico. A situação geográfica privilegiada do Estado responde pela grande variedade de ecossistemas encontrados, reunindo características de pelo menos três regiões brasileiras: Norte, Nordeste e Centro Oeste. É detentor da segunda maior costa marítima do País, em que se estende, majestoso, o único delta em mar aberto das Américas, com dezenas de ilhas, compondo um cenário de belezas inigualáveis.

No complexo das inúmeras atrações, inclui-se a mais diferenciada paisagem de todo o Brasil: o Parque Nacional dos Lençóis, com área equivalente à cidade de São Paulo - um aglomerado de lagoas, cercadas por enormes dunas, que oferecem ao visitante uma visão que transcende à imaginação; o Delta das Américas, ou Parnaíba o maior delta oceânico do mundo, que perde apenas para os dos rios Nilo, na África e Mekang, no Vietnã; as cidades de Carolina do Sul, com belas cachoeiras e piscinas de água cristalina e Codó que, por suas crendices populares e religiosas recebe muitos turistas em busca de conhecer o grande centro espírita da cidade, comandado pelo dono Bitta de Barão. No aspecto urbano, a cidade de São Luís destaca-se pela singularidade e relevância de seus aspectos histórico - culturais.

Entretanto, durante muitos anos, nenhuma ação consistente, com base num planejamento sério e aprofundado das reais possibilidades de exploração do turismo, foi objeto de metas prioritárias do Governo. Fazia-se, pois, necessária a elaboração de um projeto sustentado em dados precisos, que pudesse garantir a implementação de uma política de investimentos no setor, visando, sobretudo, à solução dos problemas sociais, pela geração de emprego e renda. 
Internamente, foram realizadas pesquisas, buscando-se definir o perfil do turista que visita o Maranhão, procurando identificar-se a opinião da própria comunidade sobre as belezas naturais e culturais, a percepção do turismo e os problemas estruturais do Estado.

GRÁFICO 2 - PERFIL DO TURISTA QUE VISITA O MARANHÃO

MARANHR̃O TEM UM FORTE

\section{POTENC RL PARA O TURISMO ATIVO}

[POTENCIAL]

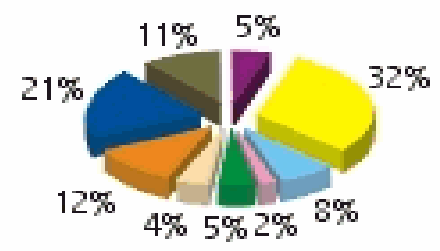

[REAL HOJE]

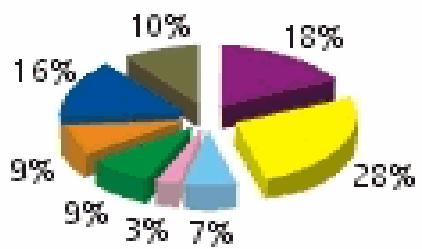

[COMUNIC A, ÃO AT UAL]

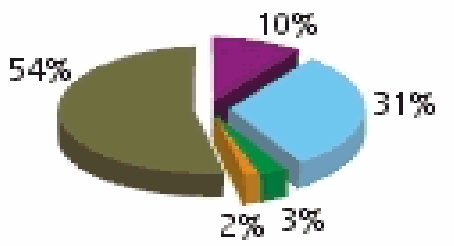

VSITIR

DINERTIR HOSPEDAR
$26 \%$

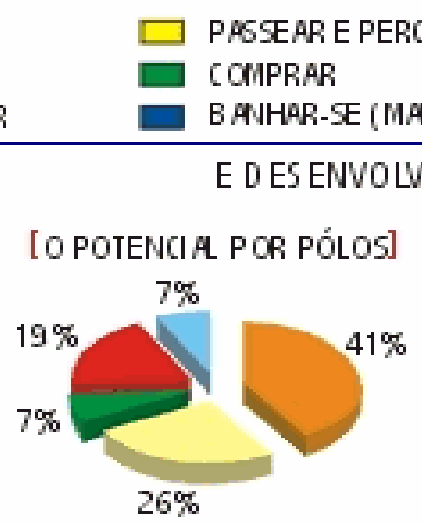

[O POTENCIA. POR PÓLOS]

PÓLO HSTÓRIC Q CULTURAL

PÓLO FEENT RÂNCIAS MARANHENSES
Páo LEN,ás

Pálo CACHCEIRAS E CHAP ADAS
[REAL HOE POR PQ́OS]

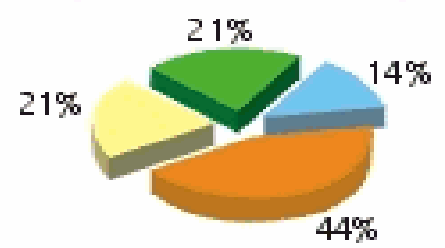

— PÓ LO DELTADO PARNÁB A $\square$ COMER E BDER
PRATICAR ESPORTE
PARTICIPAR DE FESTAS POPUL ARES

MAS FALTA MELHORAR A OFERTA 
Os principais estados emissores identificados foram os de São Paulo, Paraná, Rio de Janeiro e Rio Grande do Sul.

Já os principais receptores apresentam-se conforme tabela a seguir, notando-se a colocação do Maranhão como o décimo-segundo Estado da Federação, com uma participação de $3,8 \%$. 
QUADRO 1 - ESTADOS RECEPTORES DE TURISMO NO BRASIL - 1998

\begin{tabular}{|c|c|c|}
\hline Ordem & Estado & (\%) \\
\hline $1^{\circ}$ & São Paulo & 18,7 \\
\hline $2^{\circ}$ & Rio de Janeiro & 8,2 \\
\hline $3^{0}$ & Ceará & 7,3 \\
\hline $4^{0}$ & Paraná & 7,0 \\
\hline $5^{0}$ & Bahia & 6,9 \\
\hline $6^{\circ}$ & Minas Gerais & 6,9 \\
\hline $7^{0}$ & Santa Catarina & 5,1 \\
\hline $8^{\circ}$ & Pará & 4,9 \\
\hline $9^{\circ}$ & Pernambuco & 4,8 \\
\hline $10^{\circ}$ & Rio Grande do Sul & 4,1 \\
\hline $11^{\circ}$ & Espírito Santo & 4,1 \\
\hline $12^{\circ}$ & Maranhão & 3,8 \\
\hline $13^{\circ}$ & Goiás & 2,8 \\
\hline $14^{\circ}$ & Paraíba & 2,6 \\
\hline $15^{\circ}$ & Rio Grande do Norte & 2,3 \\
\hline $16^{\circ}$ & Piauí & 1,8 \\
\hline $17^{\circ}$ & Alagoas & 1,5 \\
\hline $18^{\circ}$ & Outros estados & 7,2 \\
\hline
\end{tabular}

Fonte: FIPE/EMBRATUR/DEPEM

A pesquisa da FIPE revela as características dos turistas que visitam São Luís e das quais se inferem as seguintes conclusões: os turistas masculinos $(58,68 \%)$ são em maior proporção que os femininos, sendo que, em janeiro de 1999, chegou a representar 70,75\%. Tem-se mantido aproximadamente a mesma proporção desde janeiro de 1997; a idade média tem variado, ainda que com uma concentração maior 
na faixa de 35 a 50 anos. O Maranhão recebe $3,2 \%$ de estrangeiros, tendo como principal destino a cidade de São Luís.

O Patrimônio Histórico-Cultural é o segundo fator decisório de atração turística do Maranhão com 17,14\%, ficando atrás apenas dos Atrativos Naturais que correspondem a 30\%. As Manifestações Populares representam o terceiro fator decisório em importância, com um índice médio de 6,09\%.

A maioria dos turistas, que visitam São Luís, declara que a escolha foi influenciada principalmente por comentário de parentes e amigos (média de 44,44\%). Observa-se, por outro lado, que é muito baixo o percentual daqueles que foram influenciados pela mídia (média de 6,67\%) e pelas agências de viagem (2,3\%).

Um dado interessante que merece destaque, nesse particular, é que $34,52 \%$ dos turistas voltam a São Luís visto suas decisões serem influenciadas pelo fato de já conhecerem a capital. É uma cifra bastante significativa na promoção do turismo, sendo que os turistas que estavam visitando o Maranhão pela primeira vez corresponde a $25,16 \%$ e - o que é ainda mais positivo - 95,88\% dos turistas declararam que pretendem voltar à cidade em outra oportunidade; quem visita São Luís utiliza avião (média de 42,165\%) e ônibus (média de 44,23\%) como os meios de transporte mais freqüentes e suas participações vêm sendo crescentes no período avaliado. De modo geral, a média de $24,7 \%$ dos turistas se hospedam em hotéis classificados de São Luís, enquanto $57,7 \%$ o fazem em casa de parentes e amigos; a permanência média dos turistas em São Luís varia entre cinco a oito dias/pessoa. (FONTE: FIPE/IPES)

As conclusões resultam da aplicação da metodologia de Fortes Oportunidades e Fracas Ameaças -FOFA, que se baseia em separar do realizado o que pode e o que não pode ser mudado: 
QUADRO 2 - OPORTUNIDADES E AMEAÇAS DO TURISMO NO BRASIL

\begin{tabular}{|c|c|c|}
\hline OPORTUNIDADES & FEITOS & AMEAÇAS \\
\hline $\begin{array}{l}\text { Proximidade com a Europa, a região } \\
\text { emissora mais importante do mundo. }\end{array}$ & \multirow{4}{*}{ MARANHÃO } & \multirow{4}{*}{$\begin{array}{l}\text { Dificuldade e alto custo do acesso. } \\
\text { Delta do Parnaíba é considerado } \\
\text { como pertencente ao Estado do Piauí. } \\
\text { Pesca predatória no Parque Nacional } \\
\text { dos Lençóis, no Delta do Parnaíba e } \\
\text { nas Reentrâncias Maranhenses. }\end{array}$} \\
\hline $\begin{array}{l}\text { Tradição do transporte marítimo e } \\
\text { fluvial. }\end{array}$ & & \\
\hline $\begin{array}{l}\text { Existência de recursos naturais únicos } \\
\text { (Parque Nacional dos Lençóis). }\end{array}$ & & \\
\hline $\begin{array}{l}\text { Artesanato original e Gastronomia } \\
\text { popular. }\end{array}$ & & \\
\hline $\begin{array}{l}\text { Crescimento rápido no Brasil e no } \\
\text { mundo. }\end{array}$ & \multirow{4}{*}{$\begin{array}{l}\text { MERCADO DE } \\
\text { TURISMO }\end{array}$} & \multirow{4}{*}{$\begin{array}{l}\text { Localização do mercado emissor no } \\
\text { Sul do País. }\end{array}$} \\
\hline $\begin{array}{l}\text { Crescimento dos segmentos do } \\
\text { turismo de qualidade. }\end{array}$ & & \\
\hline Crescimento do produto Nordeste. & & \\
\hline $\begin{array}{l}\text { Alta taxa de ocupação de mão-de- } \\
\text { obra, geração de emprego. }\end{array}$ & & \\
\hline & MARKETING & $\begin{array}{l}\text { Inexistência de planejamento integral } \\
\text { de marketing do Nordeste e da } \\
\text { Amazônia. }\end{array}$ \\
\hline
\end{tabular}


QUADRO 3 - PONTOS FORTES E FRACOS DO MARANHÃO

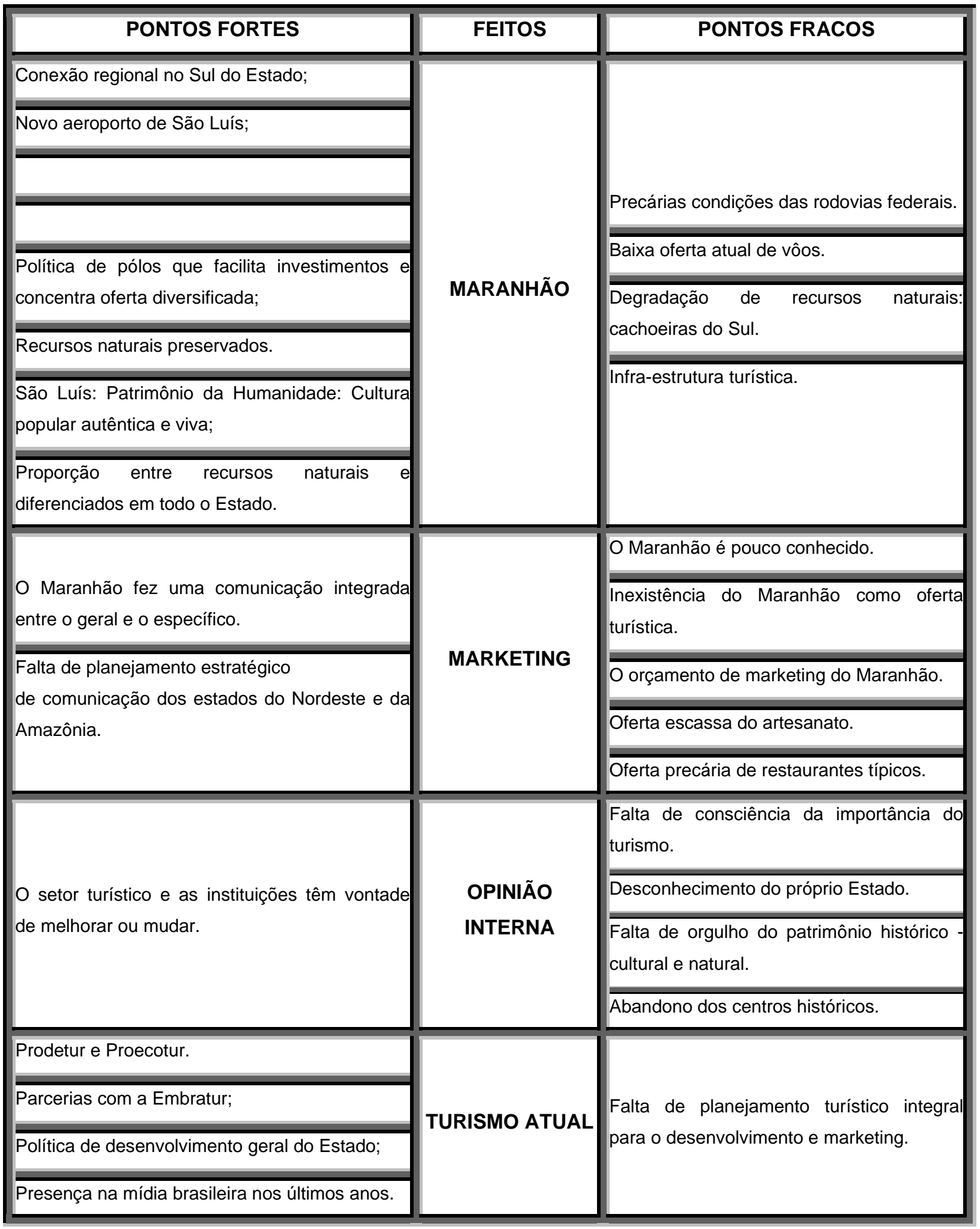


Diante da expectativa de mudança foi lançado em janeiro de 2003, o Plano de Desenvolvimento Integral do Turismo, que prevê incrementos na economia, melhoria na qualidade de vida da população, importância da preservação dos recursos naturais. A seguir, será exposto na íntegra.

\subsubsection{Macroprograma de Desenvolvimento}

Realizado o diagnóstico das potencialidades do Maranhão, verificou-se que os recursos turísticos do Maranhão foram apontados como um conjunto equilibrado, com grande potencialidade de expansão de atividades, que necessitam ser desenvolvidas de forma planejada, a fim de que a oferta seja efetiva. O desenvolvimento turístico sustentável só tem sucesso em locais que proporcionam boa qualidade de vida a seus habitantes. O Plano Maior tem por base a visão simultânea do Maranhão como destino turístico e sede da vida cotidiana de seu cidadão. Todos os esforços de melhoria e de estruturação turística do produto Maranhão trazem a idéia implícita de prosperidade para a sociedade maranhense.

Este macroprograma considera como condição básica para o crescimento turístico no Maranhão, o desenvolvimento integrado dos aspectos sociais, econômicos, urbanos e a preservação dos recursos naturais.

QUADRO 4 - OBJETIVOS DO MACROPROGRAMA DE DESENVOLVIMENTO - 2003

Objetivos

Promover o crescimento equilibrado dos produtos turísticos e gerar ofertas compatíveis com a infra-estrutura a ser implantada.

Fomentar um desenvolvimento turístico sustentável, orientado por normas e regulamentos previamente estabelecidos. 
QUADRO 5 - PÚBLICO-ALVO DO MACROPROGRAMA DE DESENVOLVIMENTO - 2003

\section{Público - alvo}

Governos Federal, Estadual e Municipais.

Agentes financiadores.

Gestores de equipamentos, serviços e espaços turísticos.

Investidores.

Comunidade.

A estratégia do Macroprograma de Desenvolvimento desdobra-se em 12 subprogramas básicos, dos quais decorrem ações específicas a serem implementadas de acordo com as características e necessidades de cada lugar.

QUADRO 6 - SUBPROGRAMAS DO MACROPROGRAMA DE DESENVOLVIMENTO

\begin{tabular}{|c|c|}
\hline \multicolumn{2}{|c|}{ Macroprograma de Desenvolvimento } \\
\hline Programas & Sub-programas \\
\hline \multirow{4}{*}{ INFRA-ESTRUTURA BÁSICA E DE SUPORTE } & SANEAMENTO BÁSICO \\
\hline & ACESSIBILIDADE \\
\hline & TELEFONIA E ENERGIA \\
\hline & CENOGRAFIA URBANA \\
\hline \multirow{4}{*}{ PLANEJAMENTO } & PLANO DIRETOR \\
\hline & REGULAMENTAÇÃO AMBIENTAL \\
\hline & DESENVOLVIMENTO DE PROJETO \\
\hline & PESQUISA \\
\hline \multicolumn{2}{|l|}{ FORMAÇÃO DE MÃO-DE-OBRA } \\
\hline \multirow{2}{*}{ REESTRUTURAÇÃO DE PRODUTOS } & EQUIPAMENTOS E SERVIÇOS \\
\hline & RECURSOS TURÍSTICOS \\
\hline \multirow{2}{*}{ ESTRUTURAÇÃO DE NOVOS PRODUTOS } & EQUIPAMENTOS E SERVIÇOS \\
\hline & RECURSOS TURÍSTICOS \\
\hline
\end{tabular}




\subsubsection{Macroprograma de Marketing}

Definir a mensagem global do Maranhão é o objetivo deste macroprograma.

A força de uma marca está na coerência que se estabelece entre ela e o produto. Uma boa marca dispensa informações complementares, fala por si só e remete diretamente ao produto; é a porta voz em todas as situações. Nas pesquisas para a elaboração do diagnóstico do Plano Maior, identificou-se o desconhecimento que o mercado internacional e doméstico tinha das potencialidades do turismo no Maranhão, e das riquezas naturais e culturais.

A informação importante na definição da marca turística do estado e de sua mensagem permanente, "Maranhão, O segredo do Brasil" é fruto da observação direta dos principais recursos turísticos do estado. Compõe-se de ícones e cores que melhor caracterizam a natureza e a cultura maranhense. É a marca geral que integra todos os pólos turísticos, estabelecendo unidade estética e conceitual entre as diferentes regiões e belezas do Maranhão.

\subsubsection{Macroprograma de Maior Qualidade}

Não se pode pensar em desenvolvimento de turismo de forma isolada. São necessárias ações integradoras, que interliguem setores e promovam o crescimento de forma global.

O Programa Qualidade tem como objetivo preparar os serviços e os produtos turísticos para a nova realidade do turismo que se pretende alcançar com a implantação do Plano Maior.

\subsubsection{Macroprograma de Sensibilização da Comunidade}

Pesquisas realizadas junto à população de São Luís demonstraram que o maranhense, de modo geral, desconhece o próprio Estado, sua história, seu patrimônio natural e suas riquezas culturais. O ludovicense tem consciência de que a questão da 
limpeza urbana é um dos problemas mais sérios da cidade; reconhece que é responsabilidade da prefeitura a coleta sistemática do lixo, mas que os moradores em nada colaboram para manter São Luís limpa. Faltam-Ihes consciência e educação.

O Macroprograma de Sensibilização da Comunidade pretende mobilizar a população, conscientizá - la quanto aos temas ligados ao turismo, à preservação ambiental e à importância de São Luís ser reconhecida como patrimônio históricocultural do Brasil e do mundo. Assim, o principal objetivo da campanha é preparar a população para o desenvolvimento do turismo no Maranhão, sem que o Estado perca sua autenticidade e suas especificidades.

QUADRO 7 - OBJETIVOS DO MACROPROGRAMA DE SENSIBILIZAÇÃO DA COMUNIDADE

Objetivos

Sensibilizar a opinião da comunidade do Estado quanto à importância que o turismo pode representar para o Maranhão.

Conscientizar os habitantes da importância de seu papel frente aos visitantes do Maranhão.

Dar continuidade ao Projeto Maracá ${ }^{5}$ - educação para o turismo nas escolas.

QUADRO 8 - PÚBLICO - ALVO DO MACROPROGRAMA DE SENSIBILIZAÇÃO DA COMUNIDADE

Público - alvo

A comunidade

\footnotetext{
${ }^{5}$ Projeto que existe desde 2001, cujo objetivo é conscientizar as crianças das comunidades maranhenses para a importância do turismo no desenvolvimento local.
} 


\subsubsection{Macroprograma de Comunicação}

O macroprograma de comunicação envolve todos os outros macroprogramas do Plano Operacional, que pretende:

QUADRO 9 - OBJETIVOS DO MACROPROGRAMA DE COMUNICAÇÃO

\section{Objetivos}

Sensibilizar a opinião dos habitantes do Estado em relação à importância do turismo para o Maranhão.

Conscientizar os habitantes da importância do seu papel frente aos visitantes do Maranhão.

Conscientizar e sensibilizar os profissionais que intervêm na prestação de serviços turísticos sobre a importância do turismo para o Maranhão e fazê-los participar dos Macroprogramas do Plano.

Conscientizar e sensibilizar os profissionais em relação a seu papel na prestação de serviços turísticos.

Sensibilizar e conscientizar os gestores de espaços turísticos sobre a importância da manutenção e controle dos espaços em benefício do desenvolvimento do turismo de qualidade no Estado.

Dar a conhecer a oferta turística do Maranhão à comunidade e aos turistas.

Fazer com que o turista compreenda os diferentes roteiros turísticos que incluem o Maranhão.

Fazer com que o turista fique satisfeito.

Dar a conhecer aos profissionais e empresários do setor, bem como aos jornalistas, a oferta turística do Maranhão e de seus diferentes pólos.

Fazer com que os profissionais do setor incluam o Maranhão nos roteiros turísticos.

Criar uma opinião favorável nos meios de comunicação.

Criar uma opinião favorável entre os operadores e os agentes de viagens.

Fazer com que os profissionais da mídia participem da comunicação do Maranhão por meio de redações e reportagens editoriais. 
QUADRO 10 - PÚBLICO-ALVO DO MACROPROGRAMA DE COMUNICAÇÃO

\section{Público - alvo}

Os profissionais que intervêm na prestação de serviços turísticos, os turistas, os meios de comunicação.

No Macroprograma de Comunicação foram criados quatro programas que irão fortalecer a divulgação do estado e o desenvolvimento do turismo local, como:

1) Programa de Oportunidades Turísticas - propõe conscientizar e sensibilizar os profissionais e gestores de espaços turísticos sobre a importância do turismo para o Maranhão, fazê-los participar dos Macroprogramas do Plano e envolvê-los no desenvolvimento do turismo de qualidade no Estado.

2) Programa de Sinalização - facilitar o conhecimento do Maranhão turístico, a locomoção interna e o acesso aos diferentes pontos turísticos.

3) Programa de Nova Identidade Turística - criar uma marca que identifique o Maranhão e o diferencie de outros estados, divulgando suas diversidades.

4) Programa de Formação - formar profissionais capacitados para atender a todos os segmentos de turistas que chegarem ao estado.

A pesquisa contribuiu para a construção do Plano de Desenvolvimento Integrado do Turismo e confirmou a variedade de recursos de São Luís que, desde 1997, porta o título de Patrimônio Histórico - Cultural da Humanidade. Constata-se ser necessário dinamizar e desenvolver esse potencial para que os recursos possam constituir um amplo conjunto de ofertas, capaz de atrair turistas brasileiros e estrangeiros.

Capital e cidade mais importante do Maranhão, São Luís oferece os melhores equipamentos e serviços turísticos. Dispõe de hotéis, linhas de ônibus interestaduais e 
intermunicipais regulares, aeroporto com oferta de vôos para vários destinos nacionais. De São Luís o visitante tem acesso a todo o interior do Estado.

Todavia, percebe-se que o turismo no Maranhão se resume aos atrativos naturais que o estado possui, esquece ou até mesmo ignora as manifestações culturais tão presentes no cotidiano da comunidade. Assim, todos os investimentos e recursos adquiridos com o turismo, certamente não irão favorecer tais festividades, como o bumba-meu-boi, tradicional no mês de junho. A cidade de São Luís recebe milhares de pessoas que chegam de outros estados do Brasil e até de outros países, tão interessados pelo folclore local que tiram fotos e filmam para relembrar um dos espetáculos mais lindos e coloridos do estado.

Não obstante tal descaso encontra-se também o reggae. No ano de 2003 , a terceira edição do Festival Maranhão do Reggae fez a capital receber milhares de pessoas em torno de artistas, muitos internacionais que compareceram à "Jamaica Brasileira" e contribuíram na divulgação do ritmo aos outros estados, que mesmo não sabendo, pois não houve divulgação, muitos participaram por estarem na cidade visitando ou por algum parente ter avisado antecipadamente.

Diante de tais observações, conclui-se que nem tudo que o estado oferece de atrativos está sendo trabalhado como produto ao turista, havendo falhas no investimento e marketing das manifestações culturais expressivas que o estado tem a oferecer. O Plano não está tão completo como se acredita, pois se esquece de que para que o turismo aconteça, não basta apenas qualidade, mas oferecer diferenciais. 


\section{O REGGAE NA JAMAICA}

\subsection{HISTÓRIA E ESCRAVIDÃO}

Inicialmente, segundo Luna (1976, pág.5), a Jamaica era habitada por índios arauaques, quando foi descoberta por Colombo, em 1494. Em um dos primeiros encontros com índios, o descobridor foi tomado por surpresa, quando pacificamente, foi recebido pelos gentios, acompanhados por uma banda, cujos únicos e rústicos instrumentos eram alguns tambores e flautas feitas de cana. Pela história de que se tem conhecimento, essa foi a primeira música a ser ouvida na Jamaica ou "Xaymaca", a "Terra das Primaveras", como era chamada pelos nativos. Infelizmente, os então descobridores não entendiam de harmonia e muitos menos de paz. O único interesse era a extração do ouro, mineral que presumiam haver em grande quantidade na ilha.

A vida dos arauaques virou um verdadeiro 'inferno', escravizados e utilizados em trabalhos forçados em minas de extração do ouro, contaminados com doenças, até desconhecidas para eles, como a gripe. Povo de tremenda passividade foi aos poucos desaparecendo daquela que era sua própria terra, seu berço, seu único universo. Tinham ainda último gesto de desencanto e total desalento, o ceifamento de suas próprias vidas, pelo suicídio, contribuindo para acelerar o processo de extinção (LUNA, 1976, pág. 8).

Os espanhóis em 1512 resolveram sair da Jamaica, pois não havia ouro suficiente para a extração, e seguiram para ilha vizinha Cuba, esquecendo-se da Jamaica. Passando-se alguns anos, em 1660, a Inglaterra disputou as terras da Jamaica com os espanhóis. Após cinco anos de batalha, venceram e libertaram os escravos.

Os escravos libertos foram procurar refúgio nas montanhas e juntamente com os últimos arauaques, formaram um grupo denominado maroons (selvagens), que não demoraria muito para deixar de ser um enorme inconveniente para a Inglaterra.

A partir de 1670, a Jamaica foi definitivamente cedida à Inglaterra pelo Tratado de Madri. Com a consciência de não mais haver quantidade suficiente de ouro para a extração, os ingleses mudaram a linha de exploração de minério para a exploração da 
agricultura e introduziram uma espécie de cana - de - açúcar na lavoura, proveniente de Barbados. (LUNA, 1976, pág. 10).

Base de economia, a agricultura dependia para seu desenvolvimento de um enorme contingente de mão - de - obra escrava. Assim, muitos africanos foram enviados para a Jamaica, constituindo-se em maioria da população.

$\mathrm{Na}$ Jamaica, os escravos refletiam sentimentos de revolta, pelos rituais (em nenhum lugar do mundo, onde pairava o regime escravocrata, via-se passividade, pelo contrário, havia manifestações de todos os tipos e graus). Os rituais transcendiam à compreensão dos senhores que, por receio ao desconhecido e para inibir possíveis revoltas moviam perseguições aos cultos. Entretanto, existiam também outros senhores que permitiam, por vezes, a formação de grupos de escravos que se aglomeravam, constituindo uma espécie de roda, normalmente em comemorações como o final de colheita ou de um dia árduo de trabalho. Bastava um casamento ou um enterro para que os negros escravos retomassem seu sentimento tribal.

\subsection{ABOLIÇÃO DA ESCRAVATURA E CONSEQÜÊNCIAS}

Com a abolição em 1833, houve a unificação da força bruta das circunstâncias e os africanos se afunilaram em vários cultos, passando a conviver uns com os outros, enfatizando a crença nos espíritos, nos deuses e nos demônios. A fé se expressava pela música, tendo o ritmo como base de qualquer transe de caráter religioso. principal batuque, burru drums ${ }^{6}$, era presença constante na maior parte dos cultos. Compunha-se de três tambores: um mais grave, que fazia o papel de baixo; outro repetidor com som mais agudo e o terceiro, um surdo feito com uma pele mais esticada, destinava-se a marcar o ritmo. Já se observavam as primeiras baladas rítmicas do reggae. (LUNA, 1976, pág.20).

\footnotetext{
${ }^{6}$ Batida forte nos tambores, para evocar ancestrais e entidades divinas.
} 
A economia agrícola sofreu um golpe severo, resultando, inevitavelmente, no aumento significativo da pobreza e gerando uma inquietação social que durou várias décadas. Posteriormente, com o advento da Segunda Revolução Industrial, nos anos 50, as bases da economia que eram rurais, passaram por um processo paliativo que viabilizou a industrialização. Como conseqüência, explodiu o êxodo rural, atraindo para a capital, Kingston, e para os arredores, trabalhadores rurais, em busca de melhores oportunidades de trabalho na cidade.

A conseqüência dessa migração desenfreada, não poderia deixar de ser outra, a não ser a concentração populacional urbana, levando ao surgimento de inúmeras favelas, onde a miséria, a fome e o desemprego reinavam, gerando como conseqüência principal, a violência.

Era imenso o grau de insatisfação social vivido pela população jamaicana que, com manifestações de vários tipos, principalmente através da música, demonstravam revolta. Os movimentos sociais, embora surtissem efeito moral, não modificaram em nada a condição socioeconômica jamaicana que continuava sob as asas dos sofrimentos herdados do período da triste e maldita herança colonial. Silva (1995, pág.4), afirma que:

A história colonial da Jamaica é partilhada por muitos conflitos e rebeliões...com a abolição da escravatura em 1833, deixaria, portanto, nos descendentes africanos, profundas marcas rítmicas e culturais, e que se tornariam mais tarde, os fundamentos ideológicos do reggae.

No início da década de 1970 em Kingston, as possibilidades de encontrar trabalho "digno" eram restritas, e a cidade transbordava com o sentimento de revolta social. A maioria dos inconformados era de jovens, conhecidos como rude boys.

Segundo Albuquerque (1997, pág. 27), "O rude boy era uma cria do gueto, tendo nascido e crescido cercado de miséria por todos os lados. Eram filhos das primeiras famílias que se mudaram para a cidade. Tinham de 15 a 18 anos, em média, distantes portanto da idade da razão." 
Eram pouquíssimas as alternativas de trabalho, com chances de apenas conseguir subempregos e com poucas oportunidades de ter qualquer ascensão, ou conseguir ascender na expectativa ou sonho de gravar e fazer sucesso com música nas rádios locais. Impossibilitados de sair do anonimato e ganhar dinheiro, a única opção dos jovens era a vida do crime e das drogas; uma ida, quase que totalmente sem volta.

Quanto ao teor das letras do reggae jamaicano, Silva (1995, pág. 42) afirma: "com as letras de cunho explicitamente social e político, tais músicas mostram a realidade da Jamaica, a fome, a miséria dos 'bairros de lata', o desemprego e as perseguições policiais, sofridas pela população pobre e negra das favelas".

\subsection{SURGIMENTO DO REGGAE}

A ilha da Jamaica localiza-se no mar das Antilhas, a $150 \mathrm{~km}$ ao sul de Cuba e $160 \mathrm{~km}$ do Haiti, com uma área absoluta de $10.991 \mathrm{~km}^{2}$. De nome oficial Jamaica tem por capital, Kingston. A língua pátria é o inglês, mas usa -se comumente uma mistura de inglês arcaico e vocabulário africano, sendo que mais de $90 \%$ da população jamaicana é de origem africana.

Durante a escravidão africana na Jamaica, era comum a predominância de orquestras formadas por escravos, usados como animadores das festas promovidas pelos fazendeiros mais ricos, durante as férias. A abolição da escravatura na Jamaica em 1833 "deixou aos descendentes de africanos profundas marcas rítmicas e culturais, e que se tornariam os fundamentos ideológicos do reggae". (DORIS; SIMON, 1983, pág. 16)

No início dos anos cinqüenta, a música popular na Jamaica era o mento, ritmo inspirado no calipso das Ilhas Trinidad e Tobago, considerado pela Igreja rude e indecente. O mento manteve também uma adaptação jamaicana de cantos de marinheiros e velhas canções folk britânicas. 
Na mesma época, o rhythm and blues começava a ser captado pelos jovens na Jamaica, durante a madrugada, pelas ondas do rádio. O som produzido pelos blacks americanos de Nova Orleans e Miami, nos Estados Unidos da América, começava a influenciar os ouvidos caribenhos dos jamaicanos.

Durante a década de 60 considerado o primórdio do reggae, a mistura do mento com o rhythm and blues, temperada pelas influências deixadas pelos tambores africanos do tempo da escravidão, originou o ska (batida nervosa com tempo acelerado), ritmo que nasceu na rua com filiação direta dos guetos e que teve adoção automática do povo. As bandas de ska animavam os navios de turistas que visitavam a Jamaica, atraídos por um ritmo diferente que "fervilhou" a Ilha por anos a fio.

A batida do ska foi alterada e novas influências rítmicas determinaram a introdução
de vocalistas nas bandas, com isso o ska "perde a força, e nas ruas as pessoas
não escutavam mais, segundo uma lenda contada pelos próprios jamaicanos, um
verão 'infernal', extremamente quente em 1966, fez com que as sound-systems
reduzissem gradativamente a velocidade do ska, tornando-o mais lento. Não se
sabe exatamente o porquê, mas o fato é que uma nova maneira de se escutar o
ritmo apareceu, com os tambores dos burru drums, dando uma batida mais forte e
sólida. Nascia no início dos anos 60 , o rock-steady , o que para os maranhenses,
corresponde ao reggae roots, que é um ritmo mais lento e romântico. Com o
surgimento do rock-steady, os artistas jamaicanos, pela primeira vez, tinham a
oportunidade de mostrar sua consciência política e musical. Com letras de cunho
explicitamente social e político, mostrando a realidade jamaicana, a fome e a
miséria dos bairros pobres, o desemprego e as perseguições policiais sofridas pela
população pobre e negra das favelas. ( SILVA, 1995, PÁG. 42).

Havia porém, problemas para conseguirem-se discos daqueles artistas ouvidos pelas ondas de rádio. Além de caros, eram raros. Para o povo, além da falta de dinheiro, não existiam lojas que pudessem oferecer algum disco. Criou-se, então, mediante a necessidade, uma solução original. Como o povo não poderia ir até os discos, os discos foram até eles, usando-se as primeiras sound-systems, caminhonetes ou caminhões equipados com alto falante de muita potência, que levavam a música até a massa, embalando o gosto musical do povo, transformando as ruas de Kingston em um verdadeiro baile ao ar livre.

\footnotetext{
${ }^{7}$ Sound-system: sistemas de som capazes de fazer mixagem de músicas, colocando-as em qualquer velocidade.

${ }^{8}$ Rock steady ou reggae roots: músicas de reggae mais antigas, conhecidas também como reggae do raiz, como o que é cantado por Bob Marley.
} 
Os donos das sound-systems tornaram-se grandes empresários da música na Jamaica, formando o "berçário" do reggae, dando os primeiros sussurros da seita rastafari ${ }^{9}$.

Nas ruas jamaicanas, os rudes boys contestavam as autoridade policiais, até mesmo de maneira violenta, incentivando todo tipo de anarquia social. Quanto mais havia repressão, mais aumentava o clube dos rudes boys. A efervescência revoltosa dos "garotos de ruas" tomou rumos tão perigosos que foi preciso utilizar a música como instrumento apaziguador para a turma jovem, com letras que pediam calma às turbas furiosas.

Em meados dos anos 70, o reggae saiu da Jamaica e invadiu o mundo, embalando manifestações políticas e questões de cunho racial. Os rastafarianos (seguidores da seita rastafari), usando cabelos compridos em forma de tranças dreadlocks, conhecidos como "cachos do medo", (usavam os cabelos dessa forma segundo o versículo da Bíblia 6:5 que diz: "nenhuma lâmina deverá tocar a cabeça do justo", dirigido a Sansão que ganharia em força espiritual) eram símbolos vivos do movimento, refletindo uma identidade cultural de oprimidos, que adotam o reggae como símbolo da expressão de suas angústias.

A palavra reggae, para alguns estudiosos do ritmo, surgiu da mistura das línguas afro - caribenha e inglesa, presentes na Jamaica, significando raiva ou desigualdade, porém, não havendo nenhuma conclusão definitiva sobre tal ligação. A palavra apareceu pela primeira vez em 1967, em um disco do grupo "Toots and Maytals", denominado "Do the reggae" cujo vocalista Toots Hibbert definiu-a como "vinda do povo", "vinda do gueto". Davis; Simon (1983, pág.23) dizem que reggae significa: "pessoas vulgares que sofrem, que não têm o que querem".

\footnotetext{
${ }^{9}$ Seita Rastafari: movimento político - religioso criado na Jamaica por Marcos Gravey na década de 20 que profetizava a coroação de um rei africano, que promoveria o retorno à "Mãe África" de todos os negros que se encontram espalhados pelo mundo através da diáspora escravocrata.
} 
Como exemplos de rastafarianos famosos, responsáveis pela divulgação mundial do reggae, há figuras idolatradas como: Bob Marley, Peter Tosh, Jimmy Cliff, Desmond Deck, Jacob Müller e outros que, embora bem menos famosos, contribuíram também com efeito favorável para a universalização do reggae. Conforme as idéias de Silva (1995, pág. 46)

O reggae demonstra sua força com acentuado caráter de contestação política, marcando uma revolução na música negra em todo o mundo, saindo em busca de novos ritmos, originando novas tendências e conquistando novos espaços, sem deixar porém, de beber da essência da fonte que originou os guetos do terceiro mundo.

O reggae concentra boa parte da expressão social, cultural e política da Jamaica, com compositores e cantores, que se tornaram profetas, críticos sociais e líderes espirituais no país. Como expressão máxima do reggae jamaicano no mundo está Robert Nesta Marley que, com a banda "The Wailers", foi responsável pela explosão do reggae para além das fronteiras jamaicanas. O sucesso internacional dos "Wailers" serviu para abrir as portas a vários cantores e compositores jamaicanos, que começaram a excursionar e a editar seus discos fora do país, desde o início dos anos 70, com uma nova proposta, arrebatando o resto do mundo com mensagens contra a discriminação racial.

O ritmo espalhado pelo mundo foi absorvido no Maranhão, em meados da década de 70 pela população negra e pobre das favelas de São Luís, como se fosse deles próprios. O reggae torna-se, então, o som da resistência negra, filho do Caribe, porém com raízes na África, bandeira de luta contra a opressão social. 


\section{DA JAMAICA A SÃO LUÍS}

Com características étnicas e sociais similares, o Maranhão e a Jamaica tornaram-se importantes cultivadores do reggae. A população negra dominante é a principal consumidora do ritmo, criando um forte elo entre os indivíduos, levando em consideração o acentuado apelo emocional.

Na entrevista ao Jornal da Massa Regueira, Beydoun (1997) afirma que "as pessoas de origem humilde curtem o reggae na Jamaica da mesma forma que a maioria da população periférica e humilde curte em São Luís também, não deixando, é claro de demonstrar seu inconformismo social".

É difícil definir exatamente quais elementos determinaram a adoção do reggae pela população maranhense, fazendo o ritmo se espalhar, principalmente entre os bairros periféricos de São Luís.

Sede da terceira maior comunidade negra do país, atrás do Rio de Janeiro e Salvador, São Luís tem nas manifestações culturais e religiosas de origem africana uma de suas maiores riquezas.

Marginalizados e em algumas épocas reprimidos, os hábitos e crenças trazidos pelos escravos e mantidos por seus descendentes são hoje reconhecidos como únicos no Brasil. Mesmo incorporando elementos culturais dos senhores e dos índios, a população de origem africana de São Luís e arredores mantém-se fiel às suas raízes.

De acordo com disk-jockey ${ }^{10}$ Neto: "a consciência dos regueiros baianos está articulada com o movimento negro, como a "Legião Rastafari", que é um elemento importante na mobilização da população negra em Salvador, que visa ao enfrentamento das práticas de discriminação racial".

\footnotetext{
${ }^{10}$ Disk-jockey: refere-se ao operador de som, conhecido também pelas iniciais "dj".
} 
O reggae de Salvador, do Rio de Janeiro e de São Luís diferem-se, pois, em Salvador, o reggae é mais uma música de envolvimento político da filosofia rastafari, assim como acontece na Baixada Fluminense, Rio de Janeiro, em que se busca o estudo do reggae como fator de cunho social. Já em São Luís, o envolvimento acontece como as "batidas" do ritmo.

O fato é que tanto o Maranhão quanto a Jamaica, por terem a população predominantemente negra, criou-se uma identidade forte entre o povos. O gosto da população negra de São Luís pelo reggae, segundo Ademar Danilo ${ }^{11}$, disk-jockey de São Luís, tem a ver com o apelo emocional que ele transmite. Os cantores de reggae cantam com uma espiritualidade que bate no fundo nas pessoas, provocando grande identidade entre São Luís e Jamaica. Não se precisa conhecer a letra para sentir o apelo emocional.

A mesma impressão é reforçada por alguns dançarinos e adeptos do reggae como a dançarina Luzia que diz em seu depoimento:

O reggae é uma música que leva a gente à vontade de se completar com ele... a gente sente assim uma loucura... não sei que é... quando eu chego no salão de dança, eu sinto assim, aquelas "pedradas"12 , eu sinto uma coisa diferente, dá vontade de dançar. É diferente de quando eu ouço outras músicas, lambadas, carimbó... no reggae tem muitas músicas que não entendo a letra, mas deixo me levar pelo ritmo.

Alguns dançarinos permanecem várias horas dançando muito próximos às caixas de som, segundo eles, "envolvidos pelo embalo contagiante do reggae, que penetra na alma e faz a gente se desligar de tudo".

Beydoun (1991) em outra entrevista, agora para o Jornal Imparcial, fez referência à proximidade entre a maneira como o reggae se instalou na Jamaica e no Maranhão, atestando uma identidade cultural entre negros maranhenses e jamaicanos,

\footnotetext{
${ }^{11}$ Ademar Danilo: um dos primeiros disk jockey a tocar reggae nos salões da ciade de São Luís, no Maranhão.

12 Pedradas: é como são chamadas as melhores músicas de reggae tocadas pelos disk-jockeys.
} 
embora os daqui não entendam a letra das músicas. Ele diz: "aquilo tudo tem a ver com ele, mesmo no nível do subconsciente, que captou a mensagem. A identidade é a mesma: o cara tá cantando lá, falando da violência policial, do racismo, a mesma coisa acontece aqui".

O reggae é traduzido como um veículo forte e legítimo de mobilização e identificação da população negra de baixa renda que habita as invasões e palafitas da cidade. As festas em sua maioria são produzidas com músicas cujos discos já estão fora de "catálogo"13 e somente alguns discotecários possuem mesmo os discos lançados recentemente que não são encontrados nas lojas de São Luís, e são comprados diretamente na Jamaica ou em Londres.

As emissoras de rádio com programas específicos não compram discos de reggae. Os programas são produzidos com material exclusivo dos apresentadores. A circulação das músicas entre a população regueira é feita principalmente pelo comércio paralelo de fitas cassete, gravados pelos disk-jockeys que importam discos ou compram as fitas já gravadas por outros; os ouvintes dos programas de rádio podem, ainda, gravar suas fitas durante as programações.

Outra semelhança entre a Jamaica e São Luís é sobre como aconteceu a difusão do reggae. Davis; Simon (1983, pág. 17) explicam que:

A ascensão do rhythm and blues nos anos 50, nos Estados Unidos fez começarem a surgir na Jamaica os sound systems, alternativa ao controle exercido pelo governo à rádio jamaicana. Eram montados por proprietários de lojas de discos, em um furgão, e munidos de uma quantidade de discos chegados de New Orleans ou de Miami; instalavam-se em algum quintal ou no mercado da região aos sábados à noite", da mesma forma como aconteceu nas ruas de São Luís, onde as caixas de som formam o paredão musical que embala os dançarinos.

\footnotetext{
${ }^{13}$ Catálogo: é como se referem às lojas de discos que vendem fitas, $C D$ e vinil de reggae.
} 
A diferença marcante com relação à Jamaica, e certamente a outros lugares onde o ritmo reggae é conhecido, é que em São Luís o reggae é dançado tanto aos pares quanto individualmente. Na capital maranhense, a dança do reggae adquiriu característica peculiar, misturando passos de forró, do merengue e do bolero.

São Luís possui características peculiares para que seja feita a divulgação do reggae. É a existência das chamadas radiolas, que são sistemas sofisticados, com até quarenta caixas de som, que geralmente contrastam com a pobreza dos salões de festas. As radiolas são operadas por um discotecário ${ }^{14}$, contratado pelos proprietários dos salões, para animar as festas em vários pontos da cidade durante toda a semana.

No início da década de 80, houve uma proliferação de radiolas, cerca de oitenta em São Luís, na disputa pela preferência dos regueiros, contando com a competência do discotecário e as condições econômicas do proprietário do clube para aquisição de novos lançamentos (exclusividades).

Curiosamente, assim como havia uma competição intensa entre os discotecários ambulantes na Jamaica que chegavam a raspar a etiqueta ou o selo dos discos mais novos, para dificultar a aquisição pelos concorrentes, em São Luís essa prática também é adotada. Há disputa muito grande pela exclusividade de um disco. Alguns proprietários de radiolas chegam a comprar todos os exemplares de um mesmo disco.

Na entrevista realizada em 21/06/2003, o discotecário André Silva afirma que existe rivalidade entre os discotecários; revela que possui discos raros, guardados na casa de sua mãe, que é um lugar mais afastado do centro de São Luís, evitando o roubo de seus discos, como já aconteceu em sua casa que foi invadida várias vezes. André confirma que para obter uma raridade, o discotecário é capaz de tudo, até contratar assaltantes para roubar o disco de quem tem.

\footnotetext{
${ }^{14}$ Discotecário: o dono de discos de reggae, normalmente, também, o disk-jockey. Muitas vezes contratado por donos de salão para tocarem nas festas.
} 
A capacidade de manter a exclusividade fonográfica garante a alguns proprietários de radiolas permanecer em evidência junto à comunidade regueira que, por sua vez, elege os melhores, independentemente do tempo de existência da radiola ou do clube. Para o regueiro, o que importa é se a radiola "bate bem", e se o discotecário conhece as "pedradas". Na gíria dos regueiros, as "pedradas" são as músicas consideradas boas, as canções mais antigas, chamadas "raízes" do reggae. São músicas muito disputadas e quem tem os discos não revela as fontes de aquisição.

\subsection{A EVOLUÇÃO DO REGGAE EM SÃO LUÍS}

A chegada do tape deck nas lojas, por volta de 1975, é apontado por Riba Macedo, primeiro discotecário a tocar reggae em São Luís, como fator determinante no processo de dinamização do reggae na cidade. O pessoal começou a comprar fitas para gravar, e o reggae se espalhou entre as pessoas que não tinham condições de adquirir os discos. Por serem importados, os discos eram de difícil acesso, além de muito caros.

O que há de comum nos depoimentos encontrados nos livros e revistas é que o reggae chegou a São Luís no embalo da discoteca, no início dos anos 70 e, principalmente, com as músicas de Jimmy Cliff, foi ganhando espaço e se espalhando na cidade.

Para os donos de radiola, o reggae é um instrumento bastante lucrativo, já que é possível para uma mesma radiola participar até de quatro festas a cada final de semana, cobrando aluguel aproximado ou equivalente a mil reais por festa.

A possibilidade de ganhos financeiros que o reggae oferece para os radioleiros ${ }^{15}$ tem gerado uma disputa acirrada pela conquista de novos espaços, no mercado, levando até mesmo a brigas corporais e ameaças de morte.

\footnotetext{
${ }^{15}$ Radioleiros: são os donos das radiolas, os que contratam discotecários para tocar em suas radiolas.
} 
As disputas, por outro lado, levaram à exigência de sofisticar, ainda mais, os equipamentos de som, não apenas com relação à quantidade dos aparelhos, para aumentar a potência sonora, mas também quanto à aquisição de novas músicas, para conquistar público. Ao satisfazer o público, cada radiola conquista uma torcida fiel, que passa a se envolver nas brigas entre as radiolas rivais.

Os disk-jockeys são reconhecidos como especialistas em reggae e têm muito conhecimento sobre os cantores jamaicanos. Com o material de qualidade e trabalho na operação da radiola e seleção da música passam a ser bastante solicitados.

Todos os disk-jockeys usam pseudônimos, relacionados ao mundo do reggae. Nomes como, Neco Pedra, Robert Marley, Fuiu Jamaica, Carlinhos Tijolada, entre outros, que servem para afirmar a identidade dessas pessoas entre os regueiros. Embora não assumam papel de liderança, alguns deles são identificados como grandes conhecedores das "pedradas" e, por isso, têm certo status entre os regueiros e donos de clubes.

Em nenhum momento os disk-jockeys revelam preocupação com o movimento regueiro em São Luís em nível da mobilização política e social. Percebe-se, entretanto, que a preocupação da maioria deles é com a afirmação do status de conhecedores das melhores músicas, o que lhes garante alguns ganhos econômicos, pois tal conhecimento possibilita boa circulação no mercado de trabalho.

\subsubsection{As Radiolas}

A mobilização dos regueiros em São Luís dá-se pelas radiolas (os sistemas de som). Algumas são tão sofisticadas que têm até monitores de TV, atuando em circuito fechado nas festas.

As radiolas dão o tom das festas, circulam pelos salões da periferia urbana de São Luís e por algumas regiões da zona rural, levando o som jamaicano. Um fator que chama a atenção é o contraste entre a sofisticação dos aparelhos e as condições de 
vida de alguns de seus proprietários. Geralmente, são pessoas que vivem em casas de aspecto rudimentar, nas regiões mais pobres da cidade, onde se concentram vilas ou palafitas formadas por ocupações de terrenos. Ao mesmo tempo, a sofisticação do equipamento e a quantidade de discos importados revelam que há um capital volumoso investido no material.

Há um comércio muito intenso e bastante lucrativo entre os radioleiros e discotecários de São Luís. A busca pela exclusividade de uma música é muito grande, gerando-se uma prática comum entre essas pessoas, que é o hábito de "segurar" um disco, para manter a exclusividade. Se uma pessoa (discotecário ou dono de radiola) tem uma música considerada exclusiva, raridade, ele a esconde dos outros. Ou seja, não toca nos programas de rádio, não grava para ninguém, apresentando somente em alguma festa especial, ainda assim com "carimbo"16.

Com o passar dos anos, a expansão do movimento regueiro em São Luís determinou a proliferação do número de radiolas e clubes de reggae na cidade. Existe, atualmente, cerca de oitenta radiolas e cem clubes especializados no ritmo jamaicano, e as radiolas vão se tornando cada vez mais sofisticadas para enfrentar a concorrência. (SILVA, 1995, pág. 76)

A proliferação das radiolas contribuiu para que o reggae se espalhasse pelos bairros da cidade. Cria-se, portanto, opção de lazer, tanto para a população de baixa renda, sem condições financeiras de comprar os discos, como para a população mais abastada, que vê no reggae um estilo a mais de diversão.

\subsubsection{Os Salões de Reggae}

Assim como as radiolas, os salões têm papel fundamental no processo de expansão do movimento regueiro em São Luís. Ali, ao som de equipamentos sofisticados dos sistemas de som, os dançarinos mostram toda a sua habilidade.

\footnotetext{
${ }^{16}$ Carimbo ou carimbar: significa colocar vinheta ou prefixos com o nome da radiola ou do disk-jockey, ao longo da execução para evitar que alguém reproduza.
} 
$\mathrm{Na}$ história dos salões de reggae de São Luís registra-se uma série de atos de invasão da polícia, com alegação de que esses espaços eram locais de concentração de marginais e desocupados. A ação da polícia visava a prender possíveis suspeitos, armas ou drogas.

Mesmo confrontando-se com tais formas de repressão, e também com outras mais sutis, veiculadas na imprensa, a população freqüentadora dos salões de reggae tem-se caracterizado como uma força de preservação do reggae roots jamaicano em São Luís. É importante frisar que a comunidade regueira de São Luís tem pouca identificação com o reggae produzido no Brasil. A preferência é pelo reggae original da Jamaica.

Apesar de estar penetrando em áreas mais nobres da cidade, os salões de reggae se constituem de certa forma, em pontas diversificadas do "território negro" em São Luís.

\subsubsection{Os Programas de Rádio}

O rádio é um dos veículos de comunicação de massa que atinge a todos os segmentos da população: o rico, o pobre, o negro ou o branco, incentivando propagandas, modelos de apresentação pessoal, de relacionamento e comportamento, além de oferecer os noticiários informativos locais. O poder de difusão dos programas de rádio é grande, com apelos emocionais como prazer, alegria, felicidade ou frustração, privação e sofrimento.

No contexto do reggae, os programas estendem ao ouvinte, sutilmente, uma versão da realidade social local. As condições socioeconômicas refletem o comportamento e o gosto diferenciado e específico pelo ritmo reggae. Os apresentadores oferecem músicas e "dicas" com opções de festas, usando linguagem em que as referências e dedicatórias são endereçadas aos lavadores de carros, às empregadas domésticas, aos camelôs e aos taxistas, demonstrando que a maioria dos 
ouvintes pertence à camada social de baixa renda. Assim os programas servem de meio apaziguador e identificador de determinada camada social.

De acordo com o redator Nivandro Vale, do Jornal da Massa Regueira (1996): "após o sucesso absoluto nos clubes, grêmio e associações, a consagração do reggae despontou no gosto popular, mas raramente uma fita ou disco, chegava à residência de algum fã, havendo, portanto, dificuldade de se escutar o ritmo".

O reggae apresenta-se simultaneamente como algo tênue e arrebatador, sendo o ponto de convergência nas regiões periféricas. Faltava o reconhecimento da população local acerca da força que o ritmo exercia sobre a ela. Esperava-se que, quando as pessoas se manifestassem, deveria ser fácil o acesso às casas dos regueiros. Isso ocorreu com o aparecimento dos primeiros programas de rádio.

Segundo Silva (1995, pág.86), "o fator que contribuiu decisivamente para a divulgação do reggae no Maranhão foi o espaço ocupado pelo ritmo nas emissoras de rádio AM e FM de São Luís, com programações específicas".

Atualmente, as rádios encontram-se integradas, no que se refere à programação de reggae. São exemplos as AMs e FMs, como: A Ilha do Reggae, Radiola Reggae, Reggae Point, Reggae Dance, Bumba Beat e Clube do Reggae.

Conforme relato do disk-jockey André Silva (21/06/2003), em 1983, a rádio Ribamar AM mantinha um locutor apresentando um programa chamado "Parada dos Astros" com a ajuda de dois amigos, Sam Baby Jr. e Sandoba que resolveram inovar o repertório de maneira até mesmo empírica, colocando seqüências de reggae. Conseguiram mexer com o gosto popular. Os locutores acertaram em cheio na preferência da "galera", provocando aumento de audiência e do tempo das seqüências, que passou de meia hora para uma hora, atendendo ao apelo e à demanda de pessoas que cobraram um volume maior de reggae. 
Impulsionado pela febre do ritmo, que já dominava os salões e clubes da cidade, surge o programa "Clube do Reggae", comandado por Jota Kerly.

O público que só ouvia os reggaes preferidos nos salões de festas, dispôs, desde aquele momento, de um programa exclusivo, gerando excelentes frutos de audiência. Em entrevista ao Jornal da Massa Regueira, Kerly (1996) afirma: "sempre acreditei que o ritmo era universal e resolvi investir na cultura da Jamaica, fazendo de tudo para provar que o ritmo era bom e que em São Luís iria fazer sucesso."

Conseqüentemente, novos programas surgiram como o Reggae Night, que durou de 1984 a 1986, comandado por Ademar Danilo e Fauzy Beydoun (atual vocalista do grupo de reggae Tribo de Jah). Durante a programação, apresentavam-se fatos e fofocas sobre os cantores da Jamaica, além da divulgação das festas semanais na ilha de São Luís. Silva (1995, pág. 87) relata:

Alguns apresentadores demonstram preocupação com a conscientização dos regueiros, procurando traduzir letras de algumas músicas e acrescentando comentários sobre questões políticas que envolvem o reggae na Jamaica. Para eles, essa é uma forma de contribuir para que o regueiro seja informado sobre o que está acontecendo no mundo, tanto com relação ao reggae, quanto com a sua própria condição de vida.

Desde então, os programas de rádio começaram a ser importantes para o mundo do reggae, pois proporcionavam lazer e entretenimento aos ouvintes que, muitas vezes, trabalhavam ao som das músicas, além de atuar como elemento de divulgação das festas e bailes.

Diante dessa perspectiva, Luís Fernando Santos Ferreira, o "Ferreirinha", proprietário de um dos maiores salões de reggae de São Luís, o "Espaço Aberto", com propósito de divulgar seu clube, freqüentado pelo público das classes média e alta da sociedade ludovicense e sua radiola "Estrela do Som", cria também um programa de rádio com a ajuda do então proprietário da rádio Difusora, Magno Bacelar. Desta forma, o reggae já massificado, gradativamente chega às classes mais abastardas da sociedade, que antes desprezava o ritmo, por ser considerado de negros e pobres. 
Com o advento dos programas de reggae, as rádios da capital maranhense começaram a ampliar as instalações e a popularizar o ritmo jamaicano, proporcionando aos ouvintes o conhecimento de novos espaços; do circuito das festas (anexo 1) e de outras atividades do universo regueiro.

O programa só é considerado bom quando o apresentador fala pouco e toca boas músicas, dando oportunidade ao regueiro de ouvir e de gravá-las, além de saber onde será a melhor festa e onde estará a sua radiola preferida.

Com a criação dos programas de rádio, o reggae, considerado música de negros desocupados em São Luís, começou a conquistar espaços além da periferia negra da cidade, conforme citado anteriormente, chegando a outros ouvidos, que despertaram para a "magia" do ritmo. Tal fato provocou um contraste interessante, pois a partir daí, parcelas da população branca, das classes média e alta que, aparentemente, nada tinham a ver com o mundo do reggae passaram a freqüentar alguns salões.

No início, o novo público adepto ao ritmo sofreu preconceito por parte da massa regueira, que só se superou com o tempo, como relata o aluno da Universidade Federal do Maranhão, Joselso Dias: "no começo foi estranho, os caras ficavam me olhando, até sabiam que eu nunca estivera ali, não só pela minha aparência, mas pela cor da minha pele. Percebi que não era bem vindo, mas foi passando o tempo, comecei a freqüentar sempre, e logo estava integrado com eles." (18/06/2003)

Na concepção dos donos de clubes e de radiolas, a programação das rádios é importante, porque aumenta as possibilidades de divulgação de suas atividades e estimula o entrosamento entre a comunidade. Sem dúvida, contribui para aumentar a freqüência às festas. 
Para o disk-jockey Ademar Danilo, os programas de rádio são fundamentais na democratização dos espaços, na divulgação das informações sobre o reggae e, ao mesmo tempo, contribui para diminuir o preconceito em relação ao pessoal que freqüenta os salões.

O rádio, além de divulgar as músicas, constitui-se também em veículo importante para manter mobilizada a população regueira para eventos de caráter explicitamente político. Um exemplo disso aconteceu nas vésperas da declaração da guerra do Golfo Pérsico em 15 de janeiro de 1991, quando um grupo de pessoas e disk-jockey, donos de clubes e de radiolas de São Luís, organizaram um ato chamado Reggae pela Paz, com o objetivo de protestar contra a declaração de guerra (SILVA, 1995 pág. 94).

Outro fato relatado por Silva mostrando o caráter mobilizador dos programas de rádio, aconteceu no dia 10 de maio de 1991, em comemoração aos dez anos da morte de Robert Nesta Marley, o "pai do reggae" como é conhecido em São Luís. Instalaramse na praça duas grandes radiolas; houve a participação de vários disk-jockeys e donos de clubes, reunindo mais de quinze mil pessoas, das dezoito às duas horas da manhã seguinte.

Com a expansão do ritmo jamaicano por São Luís do Maranhão, propiciada principalmente pelos programas de rádio, a dança do reggae deixou de ser uma atitude marginal e visto com algo bonito, entusiasmante e revelador, capaz de envolver até quem esteja só observando a satisfação pessoal dos dançarinos, que ficam lisonjeados quando escutam seus nomes divulgados através dos programas.

\subsubsection{A Dança do Reggae aos Pares ou "Agarradinho"}

De acordo com Zé Roxinho ou Carne Seca, como é conhecido em São Luís o dono de uma das radiolas mais antigas da cidade "Pop Som", atribui-se como causa ao fato de se dançar o reggae agarrado, o gosto pelo merengue e pelo forró, ritmos há muito tempo dançados na região, até pelas crianças, desde os primeiros anos de idade. 
O reggae hoje representa um dos grandes recursos para a liberação das tensões, pois, dançando as pessoas passam momentos de satisfação interior e bemestar físico, além de minorar o estresse. O swing do ritmo leva as pessoas a entregarem-se à dança.

Vidigal (1999), em reportagem sobre o reggae diz que para se compreender o reggae,

Basta abrir o coração e ouvir o reggae, para que seja despertado o íntimo das pessoas. Através da pulsação do grave cadenciado, o corpo todo será levado ao movimento por este ritmo inebriante. E, pela infiltração do som, o corpo se solta na pura expressão da alma que se deixa levar pela emoção latente do prazer de se mexer.

Com ritmo forte e pulsante, o reggae a cada dia atrai um número cada vez maior de adeptos. As academias de São Luís já o ensinam como terapia corporal. Na verdade já saiu de São Luís, como no caso do casal maranhense Natty Nayfson Henrique dos Santos e Rosemary Rodrigues, que foi para São Paulo em 1988, ensinar o gingado do reggae aos paulistas, que contagiando-se aprenderam a dançar o "agarradinho" do reggae (anexo 2), sentindo o molejo e a respiração cadenciada do outro, ou, como na Jamaica, separados, cada qual em seu próprio ritmo.

O dançarino profissional deve motivar a criatividade de cada aprendiz, observando principalmente o gingado do corpo em relação à posição do pé. O aprendiz, muitas vezes, sente-se inseguro para realizar alguns passos mais ousados, mas o profissional deve oferecer condições de espaço físico, segurança e apoio psicológico para que o aluno se entregue totalmente e não se machuque.

Para dançar-se o reggae rock, ou o reggae roots, é melhor dar os primeiros passos pela batida da bateria. Não se precisa de muita técnica, mas o regueiro, apesar de usar a emoção que brota no sentimento, também deve se apoiar no estudo minucioso de movimentos. 
Como foi dito anteriormente, o reggae traduz o significado da dança para a massa regueira do Maranhão. Faz-se, porém, a indagação: como o ritmo jamaicano ganhou tamanha força e passou a ser dançado "agarradinho", como em nenhum outro lugar do mundo?

Já em meados da década de 70 , os bailes maranhenses eram embalados por ritmos variados como forró, lambada e merengue, mas o reggae passou a ser colocado nos intervalos de músicas mais agitadas, a famosa "música lenta". Como as pessoas já tinham o hábito de dançarem juntas, era natural que o reggae também fosse dançado assim. Ao som do reggae, os clubes realizavam concursos de dança, premiando aos melhores dançarinos.

O ritmo logo foi eleito como o preferido pela maioria dos freqüentadores dos salões, portanto, há mais de trinta anos segue com força no gosto local, imune aos modismos e sem sufocar outras manifestações musicais como o bumba-meu-boi e outras manifestações que formam a riquíssima cultura maranhense. A apreciação pelo reggae não só continua forte como ganhou adeptos nos estados vizinhos, como Piauí, Pará e Ceará.

As roupas utilizadas pelos regueiros são coloridas como a bandeira da Jamaica, cuja predominância do verde, amarelo, vermelho e preto dá o colorido das vestes que transmitem paz e alegria, juntamente com as letras das músicas, que reverenciam o amor, a igualdade e a solidariedade. 


\section{O REGGAE COMO ATRATIVO TURÍSTICO EM SÃO LUÍS, MARANHÃO.}

São Luís do Maranhão, apesar de possuir oferta turística ampla, representada por atrações naturais, em especial belas praias, cortadas por rios que formam pequenos mangues, possui também oferta cultural diversificada, tanto na história, na religião, no patrimônio arquitetônico e na culinária como no modo de vida da população.

Assim como o bumba-meu-boi, manifestação cultural maranhense antiga discriminada pela sociedade da década de 60 e chamada de "estúpida e imoral, folguedo de escravos, oposto à boa ordem, à civilização e à moral", como relata o Jornal maranhense, O Imparcial, em 1961, sendo hoje a mais respeitada pela sociedade em geral, o reggae também sofreu tal repúdio há vinte anos. Isso acontece com toda forma de expressão cultural advinda dos negros, quando adotada pela comunidade periférica. Passa por um processo de "purificação", transformada muitas vezes em espetáculos turísticos, deslocando-se de sua realidade cotidiana, para que a sociedade elitista e os turistas possam também usufruir o novo "estilo de se divertir".

Passados os anos de repressões, até hoje muitos artistas tradicionalistas, representantes da cultura local, não aceitam o reggae como parte da identidade do Maranhão. Em entrevista com o senhor Francisco Silveira, dono de uma livraria local, no centro histórico da cidade soube-se: "como podemos dizer que o reggae é nosso se ele veio da Jamaica? Já temos o nosso próprio ritmo e nossa música; temos que dar mais valor a isso" (17/06/2003).

Porém, tal argumentação é vista como uma negação à própria colonização e à raça negra, como se referem alguns seguidores do reggae que o defendem como componente da tradição da cidade. Acreditam ainda que o ritmo trará muitas alegrias à localidade, pois a cada ano o turista quer conhecer mais a diversidade cultural do Maranhão. 
O reggae desperta interesse nos turistas, que chegam atraídos por seus embalos sonoros, contagiam-se pelas letras que, muitas vezes, expressam aspectos político - sociais (anexo 3) e religiosos. (anexo 4) e encantam com as estruturas dos bailes e o jeito sensual de dançá-lo.

Existe uma suposta valorização da cultura popular por meio da atuação das Secretarias de Turismo. Não se pode ignorar, todavia, que essa relação se dá sempre de forma desigual. Os órgãos públicos atuam no sentido de legitimar o controle do Estado sobre as manifestações populares, fazendo os produtores submeterem-se às exigências de programações determinadas oficialmente, dificultando quase sempre o acesso dos turistas aos locais das festas.

Percebe-se também a falta de interesse das agências de turismo e dos operadores de viagem em divulgar o reggae ou mesmo colocá-lo como mais um atrativo turístico da cidade a ser ofertado ao turista. Como exemplo cita-se a venda de pacotes de viagem para o Maranhão, no mês de agosto, que não inclui convites para o "Maranhão Reggae Festival" que acontece na cidade, com artistas nacionais e internacionais, alguns vindos da Jamaica para o evento, que acaba freqüentado apenas pela população local e cidades vizinhas. Neste ano, o festival atraiu mais de seis mil pessoas (anexo 5).Trata-se de grande manifestação cultural capaz de atrair turistas de outros estados do Brasil e até mesmo de outros países, gerando divisas para o Estado.

Compreende-se que todo atrativo turístico produz impactos positivos e negativos à comunidade e, como não poderia deixar de ser, o reggae também tem seus dois lados. Positivamente, proporciona entretenimento, prazer e diversão para quem chega e para quem é da localidade, contribuindo para abertura de novos clubes e pela manutenção dos já existentes. Geram-se empregos diretos e indiretos e entrada de divisas, contribuindo para o desenvolvimento econômico local, além de manter o sentimento tradicionalista, ao resgatar a herança africana, que é uma das mais fortes hoje existentes em São Luís. 
Dentre os efeitos negativos, segundo a Divisão de Restauração do Departamento Histórico de São Luís, está o fenômeno que ocorre na Praia Grande, bairro do centro histórico. É onde o reggae campeia mais ativamente e onde o som alto prejudica as estruturas dos prédios. Embora não possa ser percebido de imediato, a alta freqüência provoca trepidação, que se não chega a derrubar as paredes, desprende os azulejos. Também milhares pessoas que se divertem ao som das músicas de reggae, deterioram os prédios, sujam as ruas e quebram os bueiros, prejudicando a estrutura do Centro Histórico da cidade.

No âmbito da saúde, tem-se a questão da audição do ser humano que suporta apenas 80 decibéis de altura para não prejudicar o tímpano. Nas festas de reggae, o som liberado pelas radiolas é cerca de 60 mil a 65 mil decibéis de altura, levando gradativamente à surdez os assíduos freqüentadores de festas.

Foi levantada também a questão da segurança, quase sempre precária na maioria dos clubes que não possuem o essencial para a segurança, como extintor de incêndio e saídas de emergência.

A revista das pessoas na entrada dos clubes é constante, porém deve ser fortalecida, para evitarem-se fatos como o que ocorreu no extinto clube "Girafão do Reggae", antiga fábrica de sabão do Sr. João Paulo. Em 07/05/1994, aconteceu o pisoteamento de milhares de pessoas em função de um tiroteio ocorrido naquela noite, resultando num grande incêndio.

Mesmo em face dos efeitos negativos, o reggae vem conquistando contínua e gradativamente seu espaço, no âmbito do turismo e lazer. Assim como todos os atrativos turísticos, o reggae necessita de planejamento, para que se minimizem os impactos negativos que proporciona. Algumas soluções de combate aos efeitos negativos são a criação de espaços abertos para os bailes, afastados preferencialmente do centro histórico, evitando-se prejuízos às edificações; reforço na segurança dos salões, com a fiscalização de policiais, para que a diversão, principalmente dos turistas, aconteça de forma tranqüila, visando ao retorno deles. Os 
turistas, em geral, são jovens entre 15 e 29 anos, geralmente estrangeiros vindos da Europa. O que se pode notar é que muitos deles vão aos bailes em busca de mulheres nativas da região; normalmente se encantam com a sensualidade da dança do reggae "agarradinho", e até se arriscam nos passos.

Assim, observa-se que o estrangeiro a cada ano procura conhecer mais as características culturais das localidades por onde passam, sendo São Luís um dos roteiros mais visitados pela força da tradição e da história. 


\section{CONSIDERAÇÕES FINAIS}

Com raízes na África, o reggae teve a Jamaica como seu berço natal, tornandose instrumento contestador do sistema social, arma que divulgava através da música, todo seu inconformismo e revolta contra a opressão e discriminação racial.

Sendo assim, pode-se verificar a rejeição imposta ao reggae, tanto por setores das elites dominantes como por intelectuais e artistas populares. Esses últimos por estarem diretamente envolvidos com as manifestações culturais consideradas mais representativas da identidade maranhense vêem na expansão do ritmo jamaicano uma ameaça a tais tradições: principalmente por ser um produto "que vem de fora" e é consumido por uma ampla parcela da juventude local.

Se for coerente a afirmação de que o reggae ameaça a identidade maranhense, é preciso considerar, por outro lado, que a identidade cultural é constituída por um processo dinâmico de constantes transformações. É o resultado, também, da capacidade de incorporação, por determinados grupos, de novos elementos oferecidos pela modernização da sociedade urbana. (SILVA, 1995, pág. 144)

O reggae adquiriu importância como símbolo de identificação para a juventude negra dos bairros e palafitas de São Luís.

A escolha do reggae como lazer, portanto, liga-se à existência de manifestações culturais que, embora tenham passado por transformações no espaço urbano, resistem ao longo do tempo na memória coletiva. Mesmo quando as populações rurais migram para os centros urbanos, "combinando um passado rural como o presente urbano, práticas tradicionais com técnicas modernas, antigos folguedos com as novidades da indústria cultural", as manifestações permanecem em sua memória.(MAGNANI,1984, pág. 17). 
A ampla parcela da juventude negra, concentrada na periferia urbana de São Luís, mobiliza-se em torno desse ritmo como instrumento de lazer e, ao mesmo tempo, como demonstração da capacidade de criar suas próprias alternativas de identificação - ainda que tais símbolos de identificação venham de fora.

Entretanto, mesmo que alguns grupos mais tradicionais não considerem como parte das tradições culturais maranhenses, as festas de reggae constituem-se importante alternativa de lazer para a juventude negra da periferia de São Luís.

A mobilização em torno das festas de reggae representa um rompimento com as concepções tradicionalistas, que costumam apontar como únicas características possíveis de conferir identidade ao negro no Brasil, aquelas de autêntica raiz africana.

O reggae, portanto, não é só uma forma de dançar. É também uma maneira de convivência de um segmento da juventude negra de São Luís, diante das barreiras impostas pela discriminação racial.

O turismo revela-se importante atividade empreendedora, refletindo seus efeitos diretamente na economia; seu vínculo com a cultura torna-se fator primordial na divulgação da imagem de uma cidade.

Em particular, está o reggae que, no Maranhão, fez a capital São Luís ser conhecida como "Capital Brasileira do Reggae" ou "Jamaica Brasileira", conotando-se como elemento de atratividade turística muito forte, apesar dos descasos por parte das agências de viagens, operadores de secretaria de turismo local.

Conclui-se que o reggae, atualmente, faz parte do circuito de lazer da cidade, como um reflexo direto do turismo, tornando-se importante alternativa, para quem vê no ritmo uma nova opção de lazer e turismo. 
ANEXO 1 - CIRCUITO DO REGGAE. O RITMO EMBALA A MASSA REGUEIRA DE DOMINGO A DOMINGO, NOS CLUBES DA CIDADE.

\begin{tabular}{|c|c|}
\hline Domingo & $\begin{array}{l}\text { Clubão da Guia - Praia da Guia } \\
\text { Equador - Bairro São Francisco } \\
\text { Marítimu's Club e Tropical Beach- Praia Olho d'água } \\
\text { Natty Club, Toca da Praia e Trópicos Club - Praia Ponta d' areia } \\
\text { Nova Geração - Bairro Sá Viana }\end{array}$ \\
\hline Segunda feira & $\begin{array}{l}\text { Jaime Cerpa - Praia Olho d'água } \\
\text { Escolhinha do Reggae - Bairro Liberdade } \\
\text { Clubão da Ladeira - Bairro São Cristóvão }\end{array}$ \\
\hline Terça- feira & $\begin{array}{l}\text { Root's Bar, e Escadaria do Reggae - Projeto Reviver } \\
\text { Verona Clube - Bairro Fialho }\end{array}$ \\
\hline Quarta-feira & $\begin{array}{l}\text { Black Star - Bairro de Fátima } \\
\text { Clube do Bial - Bairro São Cristóvão } \\
\text { Root's Bar e Bar do Porto e Freedom- Projeto Reviver }\end{array}$ \\
\hline Quinta-feira & $\begin{array}{l}\text { Coqueiro Bar - Praia Ponta d' areia } \\
\text { Coqueiro Verde - Bairro do Anil } \\
\text { Simplesmente Maria - Bairro Coroadinho }\end{array}$ \\
\hline Sexta-feira & $\begin{array}{l}\text { Bar do Nelson - Praia do Calhau } \\
\text { Bar do Porto e Freedom - Projeto Reviver } \\
\text { Espaço Aberto - Bairro São Francisco } \\
\text { Clubão da Cohab - Associação dos moradores da Cohab } \\
\text { Papareggae - Aterro do Bacanga }\end{array}$ \\
\hline Sábado & \begin{tabular}{|l} 
Barraca de Pau - Cidade Operária \\
Bar do Nelson - Praia do Calhau \\
Espaço Aberto - Bairro São Francisco \\
Jamaica Brasileira - Bairro da Cohab \\
Papareggae - Aterro do Bacanga \\
\end{tabular} \\
\hline
\end{tabular}


ANEXO 2 - DANÇA AOS PARES OU "AGARRADINHO"

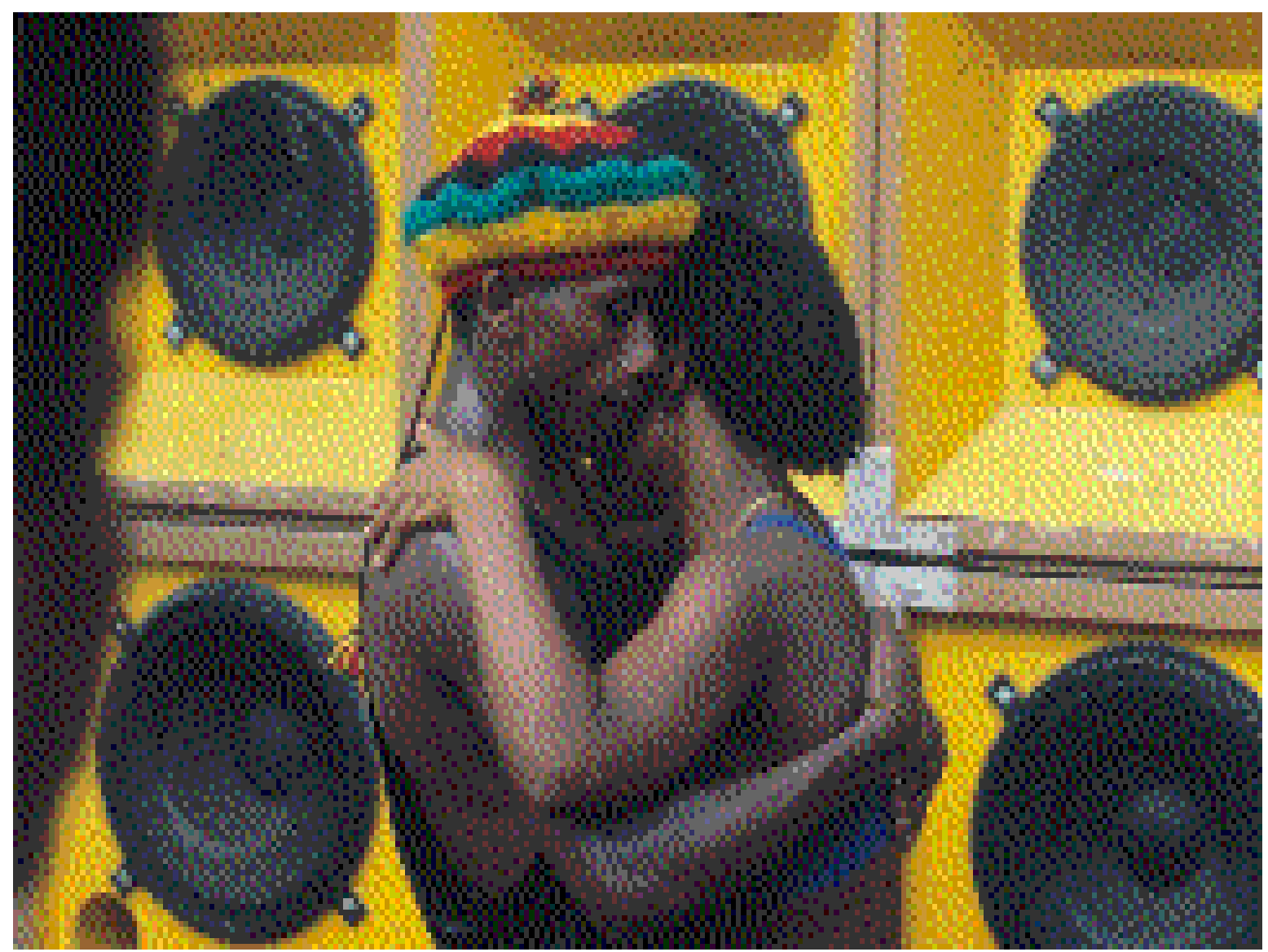

Foto: Valdemir Cunha, 2001. 
ANEXO 3 - QUESTÃO DAS DIFERENÇAS SOCIAIS, CULTURAIS E RELIGIOSAS

O reggae hoje, assim como no século passado, tinha como tema principal em suas letras, a questão das diferenças sociais, culturais e religiosas, além da reverência à mulher amada. Algumas delas retirada do $C D$ do grupo Tribo de Jah, como por exemplo:

\section{Música: referência às diferenças sociais.}

Vejo a face sofrida dessa gente

Tanta gente sofrida

Buscando uma vida decente

Buscando um pouco de paz em suas vidas

Mães que sofrem só por seus filhos pobres

E veja seus filhos

Pais que se escravizam sem ter sequer o leite e o pão de seus garantidos

Melhor nem ter com quem contar

Do que contar com quem

Com quem só quer se aproveitar

Da boa fé dos que precisam

E se dão algo, algo mais eles visam só em seu interesse se inspiram

Nada, nada de coração terão pra lhe dar

Eleve mais alto o seu pensamento

É preciso ter fé

É preciso saber dar tempo ao tempo

Dentro de si, você achará a força contida do firmamento

E Jah, então lhe proverá

Nada, nada do que for preciso lhe faltará

Do outro lado ou vejo

A soberba desses nobres senhores que

Na boa aparência escondem a sua ganância, toda a sua indecência

Bem cuidados senhores de suas riquezas

Senhores dos muitos favores

Das vantagens fáceis do poder

Senhores do tráfico de influência

Distribuem gracejos e sorrisos afáveis em seus jantares e encontros agradáveis, Disfarçam assim as suas tramas e a sua peçonha

Um dia ficarão desnudos perante a verdade e já não serão tão amáveis

Não saberão esconder os seus podres e suas vergonhas. 
ANEXO 4 - MÚSICA: REFERÊNCIA ÀS DOUTRINAS E ÀS GUERRAS ENTRE AS RELIGIÕES E O QUE ELAS REALMENTE PREGAM.

Destinos livres no mundo em degradação

Mentes mantidas na prisão

Os falsos preceitos da doutrinação

Excluídos e eleitos no reino da perdição

Líderes malignos, dominadores

Ensinam e fanatizam seus fiéis seguidores

Não sabem da dor do desprezo, da rejeição

Não sabem do desespero dos que esperam em vão

Falsos profetas, enganadores

Comerciantes da fé

Sacerdotes dos valores

Missionários, mercenários

Devotos do dinheiro

Exploram em cultos diários, o sofrimento alheio

Quanta desonestidade

Não se sabe em quem acreditar

Doutores em falsidade

Aproveitadores por todo lugar

Querem construir o seu céu na terra

$E$ acham que pra isso tudo podem comprar

Vendem suas almas, declaram a guerra

Só a cobiça lhes faz respirar

E grande a dominação

Discípulos da maldição

Quanta hipocrisia

Livrai-me dessa heresia 
ANEXO 5 - FOTO DO FESTIVAL DE REGGAE NO MARANHÃO - 2003

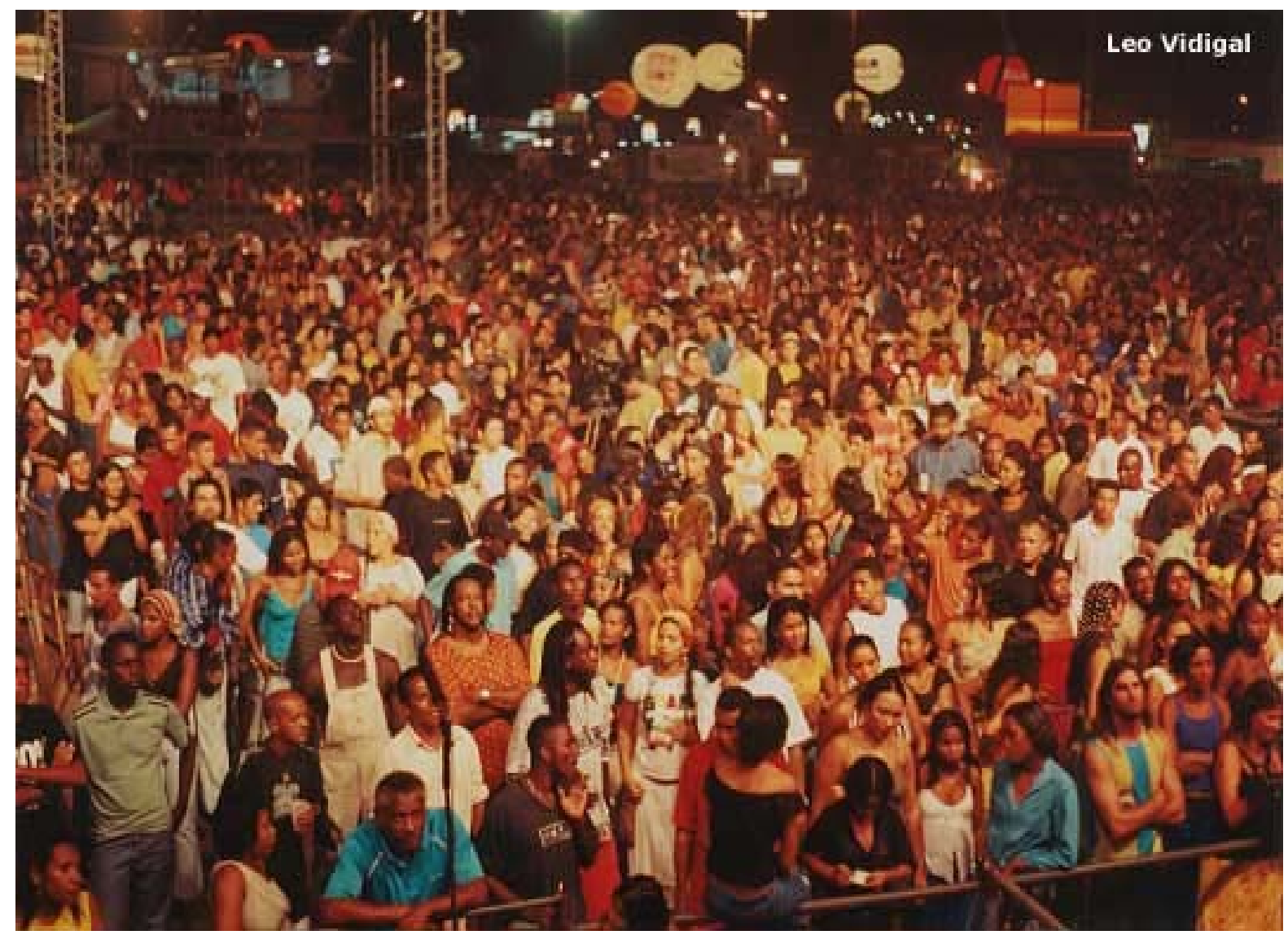

Foto de Leo Vidigal, 2003. 
ANEXO 6 - O REGGAE DE RADIOLA

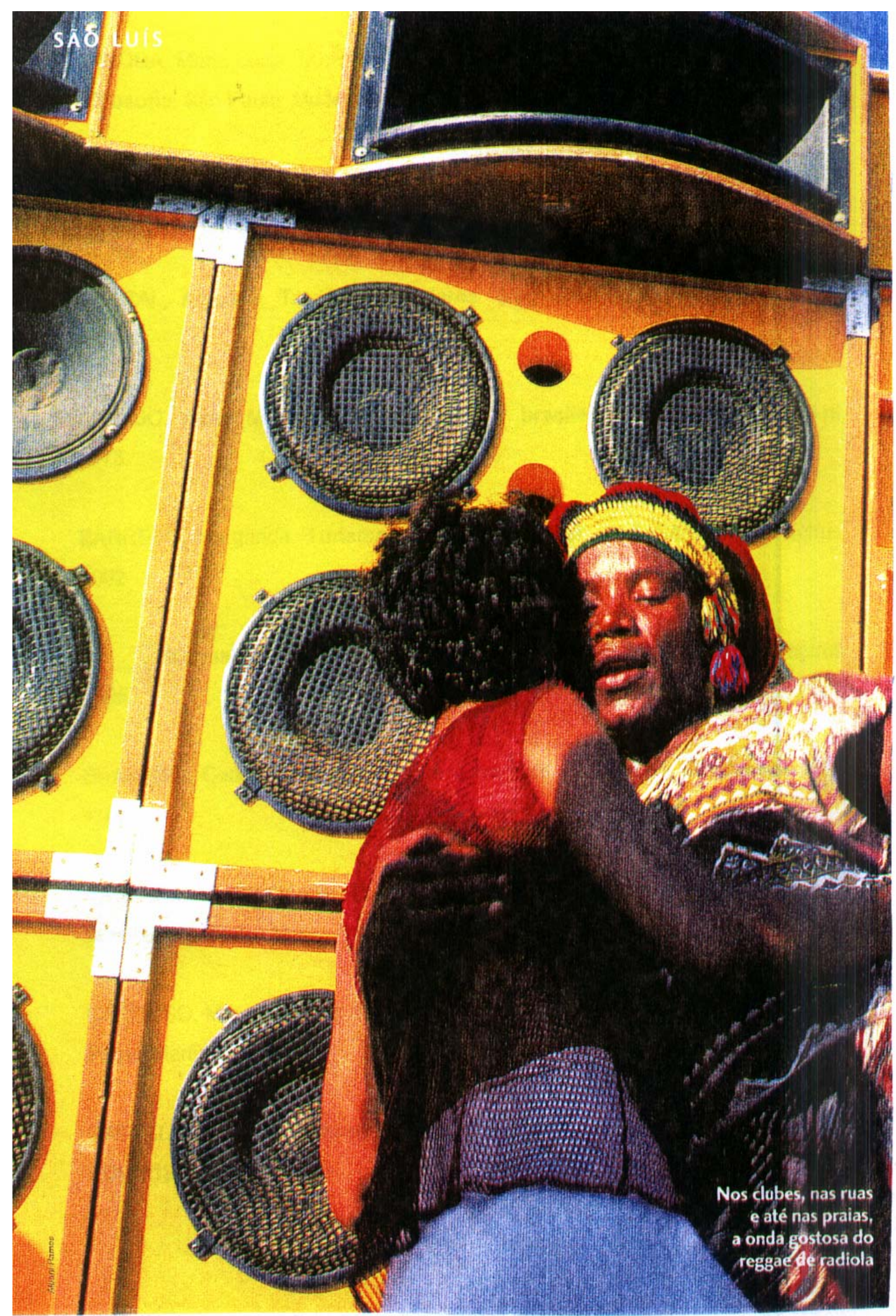

Moderna, 


\section{REFERÊNCIAS BIBLIOGRÁFICAS}

ARRUDA, Maria Lúcia; MARTINS, Maria Helena Pires. Filosofando: introdução à filosofia. São Paulo: Moderna, 1986. 441p.

ALBUQUERQUE, Carlos. O eterno verão do reggae. 34.ed. São Paulo: Coleção Ouvido Musical, 1997. 192p.

AMARAL, Amadeu. Tradições populares. 3.ed. São Paulo: HUCITEC, 1982. 441p.

ARAÚJO, Alceu Maynard. Cultura popular brasileira. 2.ed. São Paulo:[s.n], 1973.

BARRETO, Margarida. Turismo e Legado Cultural. 3.ed. São Paulo: Papirus, 2002. Manual de Iniciação ao estudo do turismo. 2.ed. São Paulo: Papirus, 1995

BRANDÃO, Carlos Rodrigues. O que é folclore. São Paulo: Brasiliense, 1993. 110p.

CANCLINI, Néstor Garcia. As culturas populares no capitalismo. São Paulo: Brasiliense, 1982. 144p.

CARDOSO, Marco Antônio. A magia do Reggae: Pesquisa e organização. São Paulo: Martin Claret, 1997.

CASTELLI, Geraldo. Turismo: atividade marcante no século XX. Caxias do Sul: EDUSCS, 1990. 128p.

DUMAZEDEIER, Joffre. Lazer e cultura popular. São Paulo: Perspectiva, 1976. 337p.

FERNANDES, Florestan. O folclore em questão. São Paulo: HUCITEC, 1978. 227P. 
FERRETI, Mundicarmo. Cultura popular: preservação e mudança. São Paulo: USP, $186 \mathrm{P}$.

Jornal da Massa Regueira, São Luís: JVC Produções, n. 5, 1996.

Jornal: O Estado do Maranhão, 8.ed. 1998.

KRIPPEENDORF, Jost. Sociologia do turismo: para uma nova compreensão do lazer e das viagens. Rio de Janeiro: Civilização Brasileira, 1989. 236p.

LUNA, Luís. O negro na luta contra a escravidão. 2.ed. Rio de Janeiro: Cátedra, Brasília, 1976.

MAGNANI, José. Festa no pedaço: cultura popular e lazer na cidade. São Paulo: Brasiliense, 1984.

MARCELINNO, Nelson Carvalho. Lazer e educação. Campinas: Papirus, 1987

MENESES, Ulpiano. Os usos culturais da cultura: contribuição para uma abordagem crítica das práticas e políticas culturais. 3.ed. São Paulo: Hucitec, 2002.

MORAES, Jomar; MEIRELES, Mário; VIEIRA FILHO, Domingos. Revista maranhense de cultura. São Luís: FUNC, 1990. 105p.

QUILIC, Cassiano; SAMPAIO, Mário. Bob Marley, mestre dinamitador. São Paulo: Brasiliense, 1986.

REQUIXA, Renato. O lazer no Brasil. São Paulo: Brasiliense. 1977

REVISTA EMBRATUR: O turismo na economia nacional e a revolução silenciosa, Brasília: Letras Brasileiras - Ministério do Esporte e Turismo, 2001. 
REVISTA SÃO LUís NO BOLSO. Maranhão: Governo do Estado, 1995

SILVA, Carlos Benedito. Da terra das primaveras à ilha de amor: reggae, lazer e identidade cultural. São Luís: EDUFMA, 1995. 168p.

Documentos consultados on line

Disponível em: <www.estadao.com.br/turismo/noticias/ 2001/mar/05/161.htm> . Acesso em 20 agosto.2003

Disponível em: <http://www.cidadeshistoricas.art.br/saoluis/sl_cul_p.htm> 